\title{
Obesity: Pathophysiology and Clinical Management
}

\author{
Tatiana Gurevich-Panigrahi ${ }^{\#, 1}$, Soumya Panigrahi ${ }^{\#, 2,3}$, Emilia Wiechec ${ }^{4}$ and Marek Los*,1 \\ ${ }^{1}$ BioApplications Enterprises, Winnipeg, Manitoba, Canada \\ ${ }^{2}$ Department of Physiology, Univ. Manitoba, Canada \\ ${ }^{3}$ Manitoba Institute of Cell Biology, CancerCare Manitoba, Winnipeg, Canada \\ ${ }^{4}$ Department of Human Genetics, University of Aarhus, D-8000 Aarhus, Denmark
}

\begin{abstract}
Obesity is a serious socioeconomic, and also increasingly clinical problem. Between $1 / 4-1 / 3$ of population in the developed countries can be classified as obese. Four major etiological factors for development of obesity are genetic determinants, environmental factors, food intake and exercise. O besity increases the risk of $t$ he development of $v$ arious pathologic conditions including: insulin-resistant diabetes mellitus, cardiovascular disease, non-alcoholic fatty liver disease, endocrine problems, and certain forms of cancer. Thus, obesity is a negative prognostic factor for longevity. In this review w e provide broad ove rview of pa thophysiology of obe sity w e a lso di scuss va rious a vailable, and experimental therapeutic methods. We also highlight functions of adipocytes including fat storing capacity and secretory activity resulting in numerous endocrine effects like leptin, IL-6, adiponectin, and resistin. The anti-obesity drugs are classified according to their primary action on energy balance. Major classes of these drugs are: appetite suppressants, inhibitors of fat absorption (i.e. orlistat), stimulators of thermogenesis and stimulators of fat mobilization. The appetite suppressants are further divided into noradrenergic agents, (i.e. phentermine, phendimetrazine, benzphetamine, diethylpropion), serotoninergic agents (i.e. dexfenfluramine), and mixed noradrenergic-serotoninergic agents (i.e. sibutramine). Thus, we highlight recent advances in the understanding of the central neural control of energy balance, current treatment strategies for obesity and the most promising targets for the development of novel anti-obesity drugs.
\end{abstract}

Keywords: BMI, BVT.933, growth hormone, TNF, PRDM16.

\section{INTRODUCTION}

Obesity is a ch ronic disease th at is increasing in prevalence $\mathrm{s}$ ince $1980 \mathrm{i} \mathrm{n}$ the Unit ed $\mathrm{S}$ tates a nd ot her pa rts of Western World. It pos es a serious risk for the development of diabetes mellitus along with insulin resistance, cardiovascular d isease, non-a lcoholic fa tty liver di sease, e ndocrine problems, and certain form s of c ancer, modestly increasing the risk of ove rall mortality. Obesity varies by a ge and sex, and by race-ethnic group. In 2003-2004, 32.9\% of adults 20 74 ye ars old we re obe se and more than $17 \%$ of te enagers (age, 12-19 years) of North America were overweight [1].

The most widely used formula for relating the height and weight of a $\mathrm{n}$ individual is body $\mathrm{m}$ ass index (BMI). BMI is defined as a ratio of we ight (kilograms) and height ${ }^{2}$ (square meters) [2]. A BMI between $20-25 \mathrm{~kg} / \mathrm{m}^{2}$ is normal and associated $\mathrm{w}$ ith lo west mortality, whereas a BMI of 2 5-30 $\mathrm{kg} / \mathrm{m}^{2}$ is considered overweight. In adults a BMI above $30-40$ $\mathrm{kg} / \mathrm{m}^{2}$ is de fined as obe sity and BMI above $40 \mathrm{~kg} / \mathrm{m}^{2}$ is severe obesity. Among the children and adolescent population with a BMI above the 95th percentile for a ge belong to the obese group [3]. Howe ver, BM I doe s not dis criminate be tween muscle and adipose tissue and does not directly assess regional a diposity [4]. S till, BMI pri marily due to its simplicity often serves a guide in treatment selection.

Regional fa $t$ di stribution ha s a profound i nfluence on health risks. In $\mathrm{g}$ eneral, measures of fa $t \mathrm{distribution} \mathrm{such}$ as waist $\mathrm{c}$ ircumference a nd sagittal a bdominal diameter a re more highly correlated $w$ ith cardiovascular disease risk factors an $\mathrm{d}$ iabetes than B MI [4]. I $t$ ap pears that the ty pical

*Address correspondence to th is a uthor at the B ioApplication En terprises, Winnipeg, MB, R2V 2N6, Canada; Tel: +49-1522-4506925; Fax: +1-(204) 334 5192; E-mail: mjelos@gmail.com

${ }^{\#}$ Authors contributed equally to this review manuscript. male (android) or vi sceral ob esity is closely associated with metabolic complications such as hypertension, insulin resistance, hype ruricemia, and dys lipoproteinemia. T he t ypical female or gynecoid obesity, with fat deposited in hips, femoral a nd gl uteal re gions, ha $\mathrm{s} m$ uch less $\mathrm{m}$ etabolic $\mathrm{c}$ onsequences. The w aist-to-hip ra tio has b een us ed to de termine these form s of obe sity. A r atio above $1.0 \mathrm{in} \mathrm{m}$ ale subjects and a bove $0.6 \mathrm{i} n$ wom en s uggests a $\mathrm{n}$ unde sirable obe sity pattern [5].

Obesity could be viewed as a consequence of the interaction of environmental fa ctors a nd the individual ge netic predisposition. A child of two obese parents has about $80 \%$ chance of becoming obese, whereas the risk is only $15 \%$ for the $o$ ffspring of $t$ wo parents of norm al w eight. In addition, obesity is strongly conditioned by a vailable food and sedentary life style [6,7].

Treatment of obe sity should be undertaken $w$ ith a clear understanding of $t$ he re alities of $t$ he probl em a nd it s outcome. B oth, obe sity a nd hi gh vi sceral fa $t$ increase he alth risks e ven whe $n$ total body we ight and fat are not significantly e levated. Weight re gain is common in obe sity upon discontinuation of any treatment. Failure of diet and exercise in the long-term treatment of obe sity is qui te fre quent and creates an obvious need for pha rmacotherapy [8]. The regulation of e nergy upta ke a nd expenditure a re controlled by complex systems, thus an improved understanding of pathophysiology is a prerequisite for selection of treatment options of obesity.

\section{ENERGY BALANCE IN THE BODY}

Fat accounts for $21-37 \%$ of the body we ight of m iddleaged $\mathrm{m}$ en a nd wom en. In $\mathrm{c}$ ase of obe se individual more calories are consumed than expended and appetite does not 
subsequently reduced to co mpensate for the in crease in en ergy $s$ tores ( $F$ ig. 1). $T$ he a mount of $t$ he adipose $t$ issue is tightly re gulated through ne ural and hum oral s ignals transmitted to the brain. Failure of fat cells to send adequate signals or fa ilure of the brain to respond to appropriate signals causes obesity [9]. An effective system for the regulation of energy balance re quire s ensors of energy s tores in a dipose tissue, mechanisms of relay of information to central control sites (hypot halamus) for $\mathrm{s}$ ubsequent i ntegration, whi ch in turn will determine food intake and energy expenditure [10].

Genetic experiments on a nimal models helped to understand the regulation of fa $t$ metabolism. Mice become obe se due to mutations of at least 5 identified genes - the $o b$ (obesity) ge ne encoding le ptin [ 11], t he $d b$ ( diabetes) g ene, agouti yellow, tubby, and fat genes. Hom ozygosity for $\mathrm{m} u-$ tant forms of $o b$ or $d b$ genes produces the following phenotype: these mice eat excessively and have low energy expenditure, they be come gros sly fat a nd s uffer from num erous metabolic a bnormalities i ncluding hyperglycemia, hyperinsulinaemia, hypot hermia, de creased t hyroid horm one a nd reduced reproductive function.

Leptin is a peptide hormone that provides signals to the brain about the amount of fat $\mathrm{s}$ tores and is secreted mainly by the a dipose ti ssue [12]. Leptin is found i $\mathrm{n}$ the blood of normal mice but no t of ge netically obe se $o b / o b$ mi ce. I f recombinant 1 eptin is injected in to the th ird o $r$ th e la teral ventricle of $\mathrm{t}$ he $o b / o b \mathrm{~m}$ ouse, it $\mathrm{r}$ educes food intake a nd weight gain, acting on neural networks of the brain involved in the control of food intake and energy expenditure. In addition, lep tin in creases th e lev el of activity in the recipient mice, normalizes body temperature and restores reproductive function (Fig. 2). Leptin mRNA is expressed exclusively in fat cells. The concentration o f 1 eptin in the $\mathrm{c}$ irculation is proportional to fat stores and BMI in normal subjects, and its secretion is pulsatile and inversely related to hydrocortisone levels [13]. The generation of 1 eptin is enhanced by gl ucocorticoids, e strogens a nd i nsulin a nd i s re duced by $\beta$ adrenergic agonists [14]. From fat storage sites leptin reaches the brain and enters by saturable transport to hypothalamus.

In contrast to leptin, le ptin re ceptor is found i $\mathrm{s}$ everal forms. The le ptin re ceptor, O B-R, is the product of $\mathrm{t}$ he $d b$ gene and it be longs to the $\mathrm{c}$ lass I $\mathrm{c}$ ytokine re ceptor fa mily. At least six OB-R splice $v$ ariants $h$ ave been identified. The most a bundant one has the longest cytoplasmic tail, and it interacts with the Jak/Stat (Janus Kinase - Signal Transducer and Activator of Transcription) signaling pathway. The long form leptin receptor belongs to the cytokine receptor superfamily. This pathway is essential for the regulation of energy homeostasis by leptin but not for the leptin-dependent control of re productive function and glucose hom eostasis [15]. Activation of PI3-K/Akt pathway as well as the downstream mTOR pa thway is a lso involved in the control of a ppetite and weight loss by leptin $[16,17]$. The shortest variant of the receptor en codes a s oluble form th at lacks the in tracellular and trans-membrane dom ains [12]. Weight ga in is not suppressed in a $d b / d b$ mouse by parabiosis with a lean mouse or by leptin injections; this suggests that these mice are defective in the re sponse to leptin as a re sult of $m$ utation in the leptin receptor [18].

Mutations in leptin and in leptin receptor have be en described at least in some obe se patients. Since large populations of obe se individuals $\mathrm{h}$ ave norm al leptin and $\mathrm{OB}-\mathrm{R}$

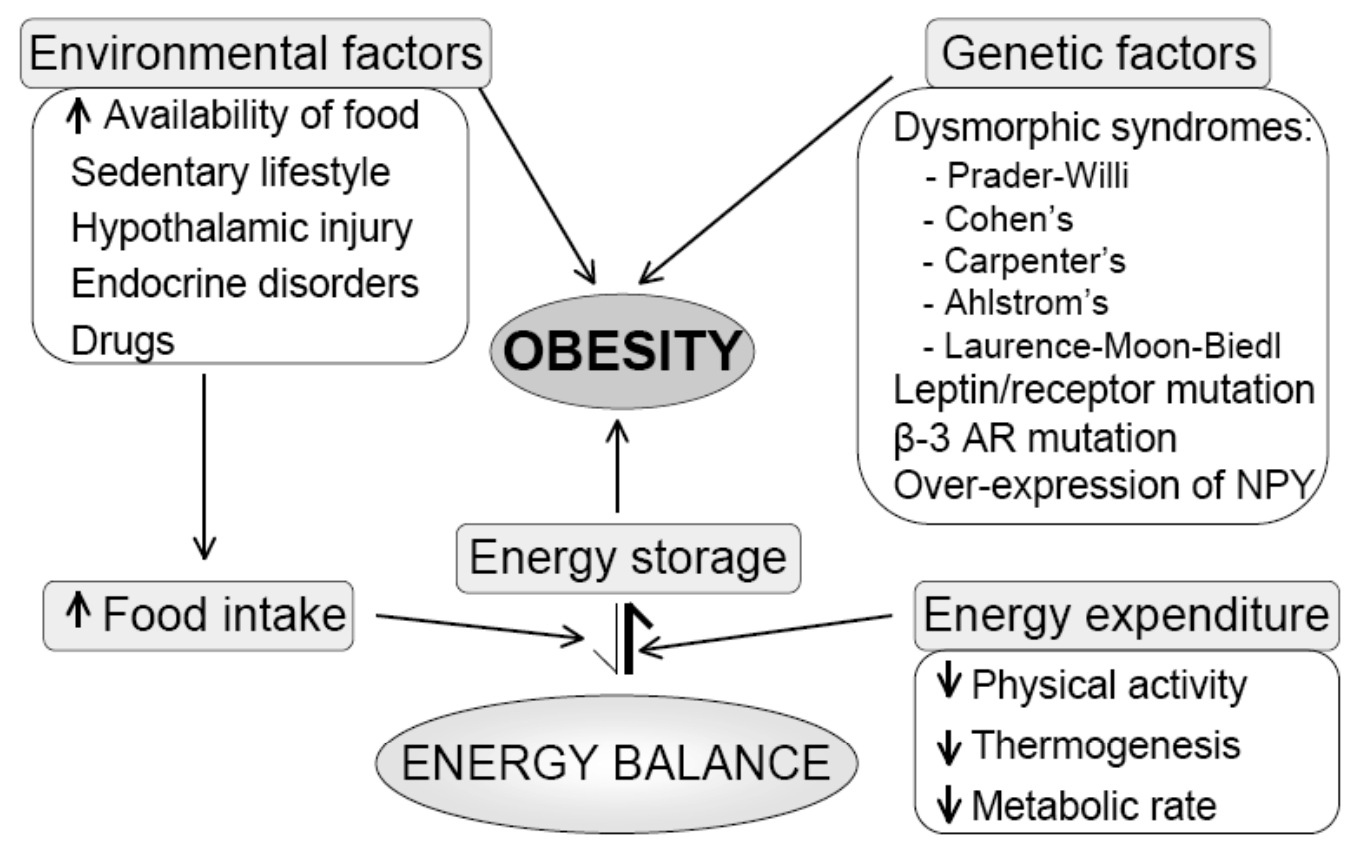

Fig. (1). En ergy balance and e tiology of obesity. Energy balance is determined by the interplay between food intake, energy expenditure and energy storage. Obesity is a multifactorial disorder resulting from combination of several environmental and genetic factors. Reduction in physical activity, metabolic rate and thermogenesis eventually decrease energy expenditure leading to increased energy storage and obesity. Availability of palatable food as well as hypothalamic injury and different drugs stimulate food intake. A growing list of genetic factors including dysmorphic syndromes, leptin/receptor mutation, $\beta-3$ AR mutation and overexpression of NPY contribute to development of obesity. 


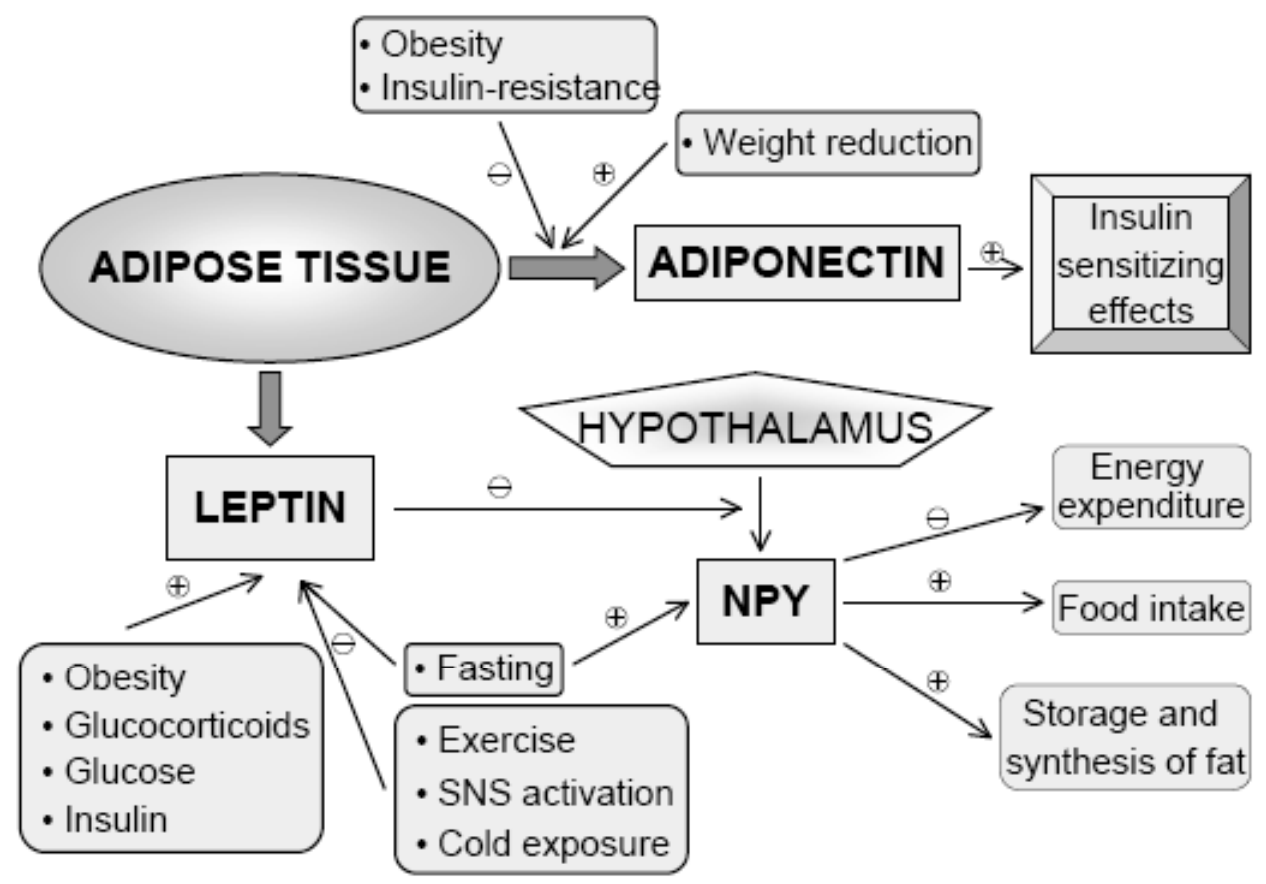

Fig. (2). Physiologic regulation and metabolic effects of leptin and adiponectin. Adipose tissue secretes leptin in states of food deprivation, SNS stimulation, exercise and cold exposure. Leptin secretion from adipose tissue is inhibited by obe sity states, glucocorticoids, glucose and insulin. L eptin reaches hypothalamus, where in turn it inhibits secretion of NPY that normally reduces energy expenditure, enhances appetite and stimulates synthesis and storage of fat. Adiponectin normally sensitizes tissues for insulin effects. Obesity and in sulin resistance negatively regulate adiponectin secretion from adipose tissue, whereas weight reduction enhances its secretion.

genes, likely obesity has multiple causes, including environmental $f$ actors a nd a ssociation of a lleles of va rious ge nes implicated in the regulation of energy metabolism [12].

Among other targets, in the brain, leptin acts on ne urons within arcuate nucleus of hypothalamus and signals them to reduce ne uropeptide Y (NPY) produc tion [19]. Food deprivation e nhances produc tion of NP Y by t he hypot halamus. NPY stimulates food intake and de creases sympathetic outflow, and through these ways lowers energy expenditure. It also prom otes s torage and synthesis of fa $\mathrm{t}$ by a $\mathrm{n}$ action on lipoprotein lipase in adipose tissue [14]. Although NPY is an important $\mathrm{c}$ omponent of $\mathrm{t}$ he re sponse, its absence can $\mathrm{b} e$ compensated by other mechanisms.

Leptin acts on ot her important ta rgets: it increases ge ne expression of $\mathrm{c}$ orticotropin-releasing fa ctor ( CRF) i $n$ the hypothalamus, which reduces food intake [18]. The action of melanocyte-stimulating hormone (MSH) may also be necessary for the response to leptin [11]. Orexins and other mediators produc ed in the hypot halamus act in central fe edback mechanisms that regulate feeding behavior [20]. Food intake and energy expenditure will finally determine the weight of an individual.

Food intake is regulated by at least four processes: olfactory and gustatory factors, gastrointestinal distension, release of gastrointestinal hormones such as insulin, cholecystokinin (CCK) and ga strin-releasing peptide and activation of $t$ hermogenic components of $t$ he e fferent $s$ ympathetic ne rvous system (SNS) [20, 21]. Most important hormones related to obesity are insulin and cholecystokinin. Serum insulin level is proport ional to the $\mathrm{m}$ ass of adipose tissue. It $\mathrm{s}$ timulates leptin release from fat cells and working centrally decreases food intake by affecting actions of CCK and NPY. However, the main action of i nsulin is to increase food upt ake by de creasing blood glucose. CCK is a peptide secreted by duodenum in the presence of food. When it acts on CCK-A receptor in the gastrointestinal tract, it decreases food intake. Circulating CCK does not cross the blood-brain barrier, but the peptide $\mathrm{s}$ ynthesized in the bra in a cts on CCK-B r eceptors and functions as a satiety factor.

The appetite-inducing hormone 'ghrelin' is derived from its prohorm one proghre lin by pos ttranslational proc essing. The presence of a nother peptide horm one called 'obestatin' was i nitially pre dicted on ba sis of $t$ he bi oinformatics da ta and la ter isolated from $\mathrm{rat} s$ tomach. Ghrelin is a ligand for growth hormone secretagogue receptor and it is synthesized in stomach $[22,23]$. Interestingly, both ghrelin and obestatin are biosynthesized from the same precursor protein but possess opposing biological properties [24]. For instance injections of ghrelin stimulate feeding in mice, whereas injections of obe statin i nhibit it. S imilarly, ghre lin increases ga stric emptying but obestatin slows it down. Ghrelin regulates the pituitary horm one axis, $m$ etabolism of $\mathrm{c}$ arbohydrates a nd different functions of the kidney, heart, adipose tissue, pancreas, and gonads as well [25]. Chronic ghre lin administration increases food intake in addition to decrease in energy expenditure. These effects lead to weight gain and possible development of obesity. In contrast obestatin seems to work as a norexic horm one and thus pre vent weight ga in [26] . Ghrelin and obe statin differ in their e ffects on growt $h$ hormone, obestatin does not seem to have any effect on growth hormone axis. This fact undermines the importance of their posttranslational modification [24]. 
Energy expenditure is de termined by phys ical activity, metabolic $\mathrm{r}$ ate and $\mathrm{t}$ hermogenesis. $\mathrm{T}$ he $\mathrm{m}$ etabolic $\mathrm{s}$ ide o $\mathrm{f}$ energy e xpenditure includes c ardio-respiratory work, t he maintenance of $i$ on gra dients and various enzymatic a ctivities. Physical activity increases energy expenditure by wor $\mathrm{k}$ of the s keletal muscle in a ddition t $\mathrm{o}$ all a bove-mentioned factors. The S NS affects not only s keletal muscle and $\mathrm{c}$ ardiovascular system but also thermogenesis [27]. Brown fat is specialized in adaptive th ermogenesis. Its th ermogenic ca pacity is pos sible through the expression of the unc oupling protein-1 (UCP-1), which uncouples oxidative phosphorylation from e lectron $t$ ransport through $m$ itochondrial re spiratory chain [28]. Brown fat cells are rich in mitochondria, and produce more heat and less ATP than white fat cells. UCP-2 occurs in both brown and white fat and is upregulated if mice are fed a high-fat diet. In humans, fat cells express the product of a gene similar to the mouse gene for UC P-2. Infants and children have much more brown fa than adults, it h as extensives ympathetic $\mathrm{i}$ nnervations. He at i s produc ed through the action of nora drenalin on $\beta$ ARs (mainly $\beta_{3}$ ) in brown fat. Activation of $\beta$ ARs increases lipolysis and fatty acid oxi dation. Int erestingly, in ge netically obe se $\mathrm{m}$ ice the expression of $\beta_{3}$ ARs is decreased [27].

\section{ADIPOSE TISSUE AND ITS PHYSIOLOGY}

\section{Physiological Features of White Adipose Tissue Innerva- tions}

The fat cell is under multiple influences, including that of autonomous ne rvous s ystem (F ig. 2), 1 ocal bl ood fl ow changes and va rious horm ones and fa ctors de livered fro $\mathrm{m}$ plasma or produc ed locally. Following S NS s timulation, noradrenaline and NPY are released from sympathetic nerve terminals, whereas adrenal medulla s ecretes adrenaline. The major pathways regulating lipolysis are adrenergic. In human fat c ells, both $\beta_{1} \& \beta_{2}$ a drenergic re ceptors (A Rs) i nitiate activation of 1 ipolytic $\mathrm{c}$ ascade by $\mathrm{s}$ timulation of $\mathrm{c}$ yclic adenosine monophosphate (cAMP) production, activation of cAMP-dependent prot ein ki nase A (PKA) leading to phos phorylation of perilipin and hormone-sensitive lipase (HSL), and prom otion of li polysis in vitro [29]. Hum an fa t c ells express large number of $\alpha_{2}$ adrenergic receptors, their stimulation inhibits cAMP production and lipolysis. Rodents possess $\beta_{3}$ adrenergic receptors in the white fat cells, whereas in human fat cells the role of the $\beta_{3}$ ARs is unclear.

Differences ex ist in the adrenergic regulation of lipolysis in adipose tissues from different sites in normal-weight subjects and in obese subjects. The lipolytic response of isolated fat $\mathrm{c}$ ells to th e c atecholamines is $\mathrm{w}$ eaker in s ubcutaneous (abdominal/femoral) than in visceral adipose tissue [30]. One possible explanation includes de fective s ignaling pa thways such as $r$ educed $\beta_{1}$ or $\beta_{2}$ A Rs or in creased $\alpha_{2}$ A R re sponsiveness. Alterations in expression and function of HS L or other interacting proteins like adipocyte lipid-binding protein (ALBP) $m$ ay a lso explain these s ite-related re gional differences in lipolysis [31].

Reduced lipid m obilization oc curs duri ng e xercise in subcutaneous fat of obe se subjects [32]. Functional changes in $\alpha_{2} / \beta_{1} \& \beta_{2}$ a drenergic $r$ eceptors $b$ alance appear wit $h$ the extent of the fat mass and are related to fat cell hypertrophy.
Hypertrophic subcutaneous fat cells (abdominal, femoral) are least responsive to the lipolytic action of catecholamins, they exhibit the highest amount of $\alpha_{2}$ ARs and the lowest amount of $\beta_{1} \& \beta_{2}$ AR $s$. Inc reased e xpression of $t$ he form er $w$ ith concomitant de crease of $t$ he la tter in hype rtrophied fat $\mathrm{c}$ ell could be a physiological adaptation leading to a reduction of the lipolytic responsiveness of the hypertrophied adipocytes [33]. Limitation of basal and SNS-dependent lipolysis avoids excessive non-e sterified fa tty acids (NE FA) $\mathrm{r}$ elease fro $\mathrm{m}$ some fat deposits.

The "buffering" effect of NEFA by a dipose tissue is an important phe nomenon. Wh en NE FA buffering c apacity is inadequate, ot her ti ssues are exposed t o elevated N EFA concentrations [34]. Profound unre sponsiveness of the subcutaneous a dipose ti ssue to li polysis by ne ural stimulation has be en de scribed in ob ese subjects [35]. $\beta_{2}$ a drenergic mediated increases in thermogenesis and lipid oxidation are impaired in obe se i ndividuals [36]. P olymorphisms in the coding and non-coding sequences in the hum an $\beta_{2}$-AR gene could be of $m$ ajor importance for obe sity, energy expenditure, a nd $\beta_{2}$-AR de pendant li polytic func tion. F ull $\beta$ adrenergic a ctivation of the hum an fat $\mathrm{c}$ ell us ually re quires synergistic a ctivation of $\beta_{1}$ a nd $\beta_{2}$-ARs. A $\beta_{2}$-adrenergic defect $\mathrm{c}$ ould be $\mathrm{s}$ ufficient e nough t o a lter norm al $\beta$ adrenergic re sponsiveness. Be sides, in hum an fa t cell, a ny reduction in $\beta_{2}$-AR mediated lipolytic response disturbs the normal func tional ba lance existing be tween $\alpha_{2}$ a nd $\beta$-AR mediated a ffects a nd amplifies reduction of $t$ he 1 ipolytic responsiveness $\mathrm{i}$ nitiated by $\mathrm{t}$ he physiological a mines in stressful situations [33].

\section{Insulin Signaling in the Adipocytes}

Insulin plays a major role in the control of adipose tis sue development and func tion. Ins ulin not onl y re gulates lipogenesis but also the rate of lipolysis and NEFA efflux. Insulin controls g lucose upt ake a nd causes fa tty a cid transport protein translocation and enhanced fatty acid uptake in adipocytes [37]. Ins ulin i nhibits ba sal and c atecholaminestimulated lipolysis through phosphorylation via the Ser/Thr protein kinase $\mathrm{B}$ (PKB) -dependent action and activation of type 3B phosphodiesterase (PDE-3B), leading to a decreased cAMP level, that pre vents HS L activation. Ins ulin-induced antilipolysis a nd a ctivation of NE FA r e-esterification a re blunted in omental compared to subcutaneous fat cells. Various functional differences have been identified at the receptor lev el and the post-receptor level of in sulin signaling cascade [38].

Other s ubstances pos sibly $\mathrm{pl}$ aying a rol e i n lipolytic pathways ar e a trial $\mathrm{n}$ atriuretic $\mathrm{p}$ eptide ( ANP), g rowth $\mathrm{h}$ ormone $(\mathrm{GH})$, and miscellaneous a gents such as $n$ itric ox ide (NO). A NP s timulation of $\mathrm{h}$ uman $\mathrm{f}$ at ce lls ac tivates cy clic GMP (cGMP)-dependent protein kinase (cGK-I type), which phosphorylates p erilipin and HS L, thus explaining lipolytic action [39]. A lthough GH treatments in a dults r educe vi sceral obesity and affect insulin sensitivity, the physiological contribution of $\mathrm{GH} t \mathrm{o}$ the control of hum an a dipose tissue lipid mobilization remains elusive [33]. GH dependent modification of $\mathrm{t}$ he re lationships be tween a denylyl cyclase a nd $\mathrm{Gi}_{2}$ prot ein re moves i nhibition of $\mathrm{c}$ AMP produc tion a nd consequently increases li polysis [40]. $\mathrm{N} \mathrm{O}$ or re lated $\mathrm{r}$ edox 
species s uch as $\mathrm{NO}^{+} / \mathrm{NO}^{-}$ha ve $\mathrm{b}$ een propos ed as pote ntial regulators of 1 ipolysis in rode $n t$ and hum an fa t cells [41] . Cachexia-inducing tumors produce a lipid-mobilizing factor (LMF), a nd induction of 1 ipolysis by L MF w as a ssociated with increased lev els of in tracellular cAMP [42]. Z AG is a new a dipose ti ssue prot ein $t$ hat $m$ ay be $i$ nvolved i $n t$ he modulation of 1 ipolysis in a dipocytes. $Z$ inc- $\alpha_{2}$-glycoprotein (ZAG) an d tu mor $r$ elated L MF w ere $d$ etected in $m$ ajor $f$ at deposits i $\mathrm{n} \mathrm{m}$ ice. $\mathrm{Z}$ AG e xpression a nd prot ein wa $\mathrm{s}$ a lso found in hum an fat cells [42]. Various horm ones and a utacoids are known to negatively control adenylyl cyclase activity and inhibit cAMP production and lipolysis in fat cells. In addition, $t$ he $s$ timulation of 1 eptin $s$ ecretion wa $s$ obs erved with va rious a gonists $\left(\mathrm{A}_{1}\right.$-adenosine, $\alpha_{2}$-AR, a nd NPY-Y 1 receptor agonists) [33].

\section{Functional Roles of Adipocytes}

Adipocytes a llow surplus en ergy to be s tored a s triacylglycerol (TAG) during caloric abundance for retrieval during periods of food s hortage or calorie debt. NEFAs appear as a result of lipolysis of TAG stores; they are released into circulation a nd $\mathrm{m}$ ainly oxi dized i $\mathrm{n}$ s keletal $\mathrm{m}$ uscle $\mathrm{t}$ o provi de energy. Unde $\mathrm{r}$ norm al conditions there i s fi ne-tuning be tween TAG $\mathrm{s}$ ynthesis and 1 ipolysis. $\mathrm{S}$ o a dipocytes $\mathrm{c}$ ould limit an abnormal increase in plasma NEFAs that is considered as an im portant et iological factor in the in itiation of insulin re sistance a nd metabolic s yndrome in the obe se. NEFAs are elevated in obese and represent a $r$ isk factor for the development of type 2 diabetes [43].

Another i mportant func tion of a dipocytes is their c omplex secretory activity. A number of pe ptide horm ones and pro-inflammatory c ytokines ( adipokines) s ecreted by the adipocytes exert numerous endocrine effects. Among them is the previously mentioned leptin, which derives from subcutaneous fat depots. Adipocytes size and anatomical location appear to be the major determinants of leptin mRNA expression. In vivo, overfeeding and obesity, glucocorticoids treatments, glucose, and insulin administration increase circulating leptin le vels, wh ereas fa sting, s ustained exercise, cold exposure, and SNS activation reduce leptin levels [44].

An important secretory product of the adipocytes is Interleukin-6 (IL-6). P lasma IL-6 c oncentration i s i ncreased in obese subjects and correlates with fat mass and BMI. High levels of IL-6 are found in type 2 diabetes and correlate with fasting insulin levels. In s ubcutaneous adipose ti ssue IL -6 secretion in creases f ollowing ex ercise w ith co ncomitant increase in N EFA out put, wh ich s uggests a pos t-exercise lipid-mobilizing contribution of the cytokine [45].

Adiponectin is a n a dipocytes-derived insulin-sensitizing hormone, whi ch is s ecreted in hi gh concentrations in the serum. Adiponectin concentrations are reduced in a variety of obe se and insulin-resistant s tates [46]. Hypoadiponectinemia is closely linked to impaired vasoreactivity and endothelial dysfunction in humans. Adiponectin may play a protective $\mathrm{r}$ ole ag ainst a therosclerotic $\mathrm{v}$ ascular ch anges [ 47]. Adiponectin e ffects a re $m$ ediated by a denosine $m$ onophosphate activated protein ki nase (A MPK) that increases fa tty acid oxidation during muscle contraction and re presses ke y enzymes of $\mathrm{gl}$ uconeogenesis i $\mathrm{n}$ he patocytes. A MPK a lso mediates in sulin-sensitizing ef fect o f ex ercise, s ome an ti- diabetic a ctions of $\mathrm{m}$ etformin, and le ptin a ction on $\mathrm{s}$ keletal muscle [48]. Unli ke ot her a dipokines a diponectin i s de creased in obe sity and i ncreased in we ight re duction. The mechanisms th at $\mathrm{d}$ etermine in ter-individual $\mathrm{v}$ ariability o $\mathrm{f}$ adiponectin secretion, he nce a ffecting body fa tness, r emain to be clarified [33].

Resistin is a $10-\mathrm{kDa}$ adipocyte-secreted protein that possesses hormonal properties that have been claimed to represent and an important link between obesity and insulin resistance [33]. In $\mathrm{m}$ ice re sistin administration c aused gl ucose intolerance an d in sulin r esistance. In ad dition, s erum l evels of resistin were higher in mouse models of obe sity and decreased after pe roxisome proli ferator-activated $\mathrm{r}$ eceptor $\gamma$ (PPAR $\gamma)$ a gonist treatment. Whit e a dipose tissue re sistin mRNA and serum protein levels dropped during fasting and increased during refeeding [49]. The ro le of re sistin in hu man insulin resistance remains quite controversial [33].

Adipose tissue of $\mathrm{t}$ he obe se e xpresses several proinflammatory prote ins such a $\mathrm{T}$ NF $\alpha$ and $\beta 1$, IL - 1 , IL -6, inducible nitric oxide synthase (iNOS), monocyte chemotactic prote in ( $\mathrm{MCP}-1)$, proc oagulant pla sminogen activator inhibitor-1 ( PAI-1), fa ctor $\mathrm{V}$ a nd tissue f actor a nd acute phase (s erum amyloid 3, $\alpha$-1-glycoprotein, a nd li pocain 24p3). T NF i s increased i $\mathrm{n}$ fa $\mathrm{t} \mathrm{c}$ ells in obe sity and $\beta$ adrenergic stimulation is a positive regulator of TNF expression, whereas GH and PPAR $\gamma$ activators suppress its expression. Regulators of $\mathrm{T}$ NF produc tion in a dipocytes $\mathrm{m}$ ight modulate insulin sensitivity via this cytokine [33].

Two recent studies have led to a major breakthrough in the understanding of the origin and the role of TNF and other cytokines in obesity $[50,51]$. They have shown that macrophages a ccumulate in the adipose tissue of obe se mouse strains and in human adipose tissue. Macrophage accumulation oc curs in proportion to adipocyte size and it increases the $\mathrm{c}$ apacity for produc tion of pro-i nflammatory and acute phase molecules that contribute to obesity - related disorders. Thus, the a dipose ti ssue $m$ acrophages could be largely re sponsible for the major part of adipose tissue TNF, IL-1, IL6 , MC P-1, a nd iNOS expression. Release of $m$ acrophage TNF an d I L-6 $\mathrm{m}$ ay co ntribute to lo cal d ecrease in in sulin sensitivity of fa t cells and to all o ther re lated di sturbances [52].

\section{PATHOGENESIS AND ETIOLOGY OF OBESITY}

\section{Obesity as a D isorder of the Homeostatic Control of En- ergy Balance}

Although it is known $t$ hat a disturbance of the hom eostatic mechanisms controlling energy balance causes obesity, it is less clear how the balance is disturbed, since the mechanisms are very complex and involve numerous systems in the body. Soon after the first demonstration of l eptin deficiency and leptin receptor dys function in mice, it was thought that alterations in leptin kinetics might provide a simple explanation of how energy balance was disturbed in obese subjects. But most of i nformation on le ptin w as derived from rodent experiments. Plasma leptin is higher in obese subjects compared with normal weight individuals. In fact, leptin concentrations are proportional to body fat mass in both obese and lean subjects [53]. Thus, obesity is not due to the deficiency 
in $\mathrm{c}$ irculating le ptin. Resistance to le ptin $\mathrm{m}$ ight be one of factors in development of obe sity. Such resistance could be at the level of carriage of leptin in the circulation or its transport into the central nervous system (CNS) [54]. Defects in the le ptin receptor (as in $d b / d b$ mice) or in the transducing system - de creased expression of C RF or ove rexpression of NPY c ould re present ot her di sturbances i $\mathrm{n}$ le ptin s ystem [55].

Dysfunctions of $\mathrm{m}$ ediators ot her than le ptin a re implicated in obesity. TNF, another cytokine that relays information from fat to brain, is in creased in the ad ipose tis sue of insulin-resistant obese individuals [56]. It has been suggested that UCP-2, a protein uncoupling oxidative phos phorylation in white fat cells is dys functional in obese individuals [21]. Alterations in PPAR tr anscription factors $\alpha, \beta$ and $\gamma$ ma $y$ have a ro le in obe sity. These transcription fa ctors prom ote lipogenesis and regulate gene expression of enzymes associated with lipid and glucose homeostasis. PPAR $\gamma$ is preferentially expressed in adipose tissue and has a synergistic action with a nother transcription factor $\mathrm{C} / \mathrm{EBP} \alpha$, to prom ote c onversion of pre-adipocytes to adipocytes. The gene for UCP in white a dipose tissue ha $\mathrm{s} r$ egulatory $\mathrm{s}$ ites for P PAR $\gamma$ an $\mathrm{d}$ C/EBP- $\alpha$ [57].

\section{Genetics and Obesity}

Genetic determinants can either play a $m$ ajor role in the pathogenesis of obe sity or e nhance s usceptibility to it s de velopment. The dysmorphic forms of obesity in which genetics p lay a $\mathrm{m}$ ajor ro le include the $\mathrm{P}$ rader-Willi syndrome, Ahlstrom's s yndrome, the Laurence-Moon-Biedl s yndrome, Cohen's s yndrome, a nd Ca rpenter's s yndrome [7]. R eportedly, $244 \mathrm{~g}$ enes, whe $\mathrm{n}$ mutated in the mouse, $r$ esult in a $\mathrm{n}$ obese phe notype. A grow ing num ber of $s$ tudies indicate associations be tween $\mathrm{DN}$ A $\mathrm{s}$ equence va riation in $\mathrm{s}$ pecific genes a nd the oc currence of obe sity. Inte restingly, the involvement of $22 \mathrm{~s}$ uch ge nes $\mathrm{w}$ as $\mathrm{r}$ eported in at le ast $\mathrm{f}$ ive separate s tudies. The obe sity ge ne $\mathrm{m}$ ap s hows putative loci on all chromosomes except $\mathrm{Y}$ [58].

In the $o b / o b$ mice both copies of the leptin gene are defective re sulting i n t runcated prot ein. Unli ke in hum ans, treatment of obese mice with leptin reduces both food intake and body fat. Splicing de fects on the leptin receptor are responsible for the obesity in the $d b / d b$ mouse, which is phenotypically s imilar to the $o b / o b$ m ouse. The $g$ ene $d$ efect called $t u b \mathrm{r}$ esults in a de fective phos phatase a nd causes retinitis pigmentosa and obesity in mice, making it similar to the Laurence-Moon-Biedl syndrome in humans [7].

Linkage of hum an obesity to o ther factors related to energy balance has been reported. For instance, the Trp/64/Arg mutation of the human $\beta_{3}$-adrenergic receptor $\left(\beta_{3}-\mathrm{AR}\right)$ gene is as sociated $w$ ith an e arlier age of o nset of $N$ IDDM an $d$ characteristics of insulin resistance as well as weight gain in patients w ith morbid obe sity. How ever, such findings have not be en c onsistent i n di fferent e thnic popul ations [59]. It has $b$ een $r$ eported th at $p$ lasma I L-8 lev els ar e in creased in obese subjects. IL-8 is related to fat mass and TNF system. Elevated circulating IL- 8 could be one of the factors that link obesity to greater cardiovascular risks [60]. Most of genomic studies in hum ans, de monstrated substantial ge netic he terogeneity influencing BMI regulation [61].

\section{Environmental Factors and Obesity}

Environmental factors interact with genetic susceptibility in the pa thogenesis of obe sity. For e xample, hypot halamic injury from trauma or surgery and destructive lesions in the region of the ventromedial or the paraventricular nuclei can produce obe sity. The two $\mathrm{m}$ ajor $\mathrm{f}$ actors i $\mathrm{n}$ hypot halamic obesity are hyperphagia and a disturbance in the ANS activity. One explanation for $t$ his is a ltered s ecretion of NP Y, which is produced in arcuate nucleus and stimulates eating [62]. Other pos sible explanations a re impairment in re productive $\mathrm{f}$ unction, $\mathrm{d}$ ecrease in s ympathetic and in crease i $\mathrm{n}$ parasympathetic a ctivity - ot her ke y fe atures of hypot halamic obe sity [63]. Endocrine di sorders s uch as Cushing's disease, pol ycystic ov ary s yndrome and a dministration o f some drugs (phenothiazines; such as chlorpromazine, antidepressants; a mitriptyline, an tiepileptics; v alproate, s teroids; glucocorticoids, a ntihypertensive a gents; te razosin) $\mathrm{m}$ ay b e associated with obesity $[64,65]$.

\section{Food Intake and Obesity}

A typical obese subject has usually put on $20 \mathrm{~kg}$ over 10 years. This means that there $h$ as been a daily excess of energy input ov er out put of 30-40 kc al initially, i ncreasing gradually to maintain the increased body weight. The type of food eaten can play a role in disturbing the energy balance. Fat has more calories per gram compared to carbohydrates or proteins. $\mathrm{T}$ here a re $9 \mathrm{c}$ alories pe $\mathrm{r}$ gr am of di etary fa $\mathrm{t}$, whereas caloric value of carbohydrates and proteins is only 4 calories. It is possible that the mechanisms regulating appetite react more slowly to fat than to protein and carbohydrate, so satiety systems come in to the picture too late. Increase in density of foods, port ion s ize, be tter pa latability of food, increase in a vailability and low cost prom ote ob esity [66]. Obese people try to diet to lose w eight. But when a subject reduces calorie in take, there is a s hift in to n egative en ergy balance. An individual loses weight but, in parallel, the resting $\mathrm{m}$ etabolic ra te de creases, and there is a concomitant reduction i n e nergy e xpenditure. $\mathrm{P}$ robably, the s ystem is trying to re turn the body we ight t o the "set-point", whi ch implies maintenance of e nergy balance is dependent on numerous metabolic fe edback loops that are tuned by a $n$ individual's s usceptibility ge nes. Thus, an individual who wa s previously obe se and is now of norm al w eight, ge nerally needs $\mathrm{f}$ ewer calories $\mathrm{f}$ or $\mathrm{m}$ aintaining that $\mathrm{w}$ eight th an $\mathrm{a}$ individual who has never been obese. The decrease in energy expenditure appears to be largely due to an alteration in the conversion e fficiency of c hemical e nergy t o m echanical work in s keletal $\mathrm{m}$ uscle. $\mathrm{T}$ his ad aptation to the $\mathrm{c}$ aloric $\mathrm{r}$ striction contributes to the difficulty of $m$ aintaining we ight loss by diet [67].

\section{Physical Activity and Obesity}

Physical activity can be broadly divided into exercise and non-exercise a ctivities. Non-e xercise activities $\mathrm{i}$ nclude employment related work and the activity of da ily living. It is difficult to measure the energy expended in non-exercise activity. In general, an increase in sedentary behavior, and a decrease in activity of daily living and employment physical activity prom otes obe sity [68]. It i s now re cognized that increased energy expenditure by physical activity has a more 
positive rol $\mathrm{e}$ in re ducing fa $\mathrm{t} \mathrm{s}$ tores a nd a djusting e nergy balance in th e o bese, e specially when it is co mbined w ith modification of the diet. $\mathrm{N}$ ative population $\mathrm{s}$ tudy gi ves a $\mathrm{n}$ example. M any y ears ag o, a tr ibe of $\mathrm{P}$ ima Indians $\mathrm{w}$ as $\mathrm{d}$ ivided into two groups : one of them settled in Mexico and continued with simple life, eating frugally and spending most of t ime in ha rd phys ical work. They a re us ually le an and have low incidence of NIDDM. Another group moved to the USA - an environment with easy access to calorie rich food and less need for hard physical work. They are on average 57 pounds he avier than the Mexican group a nd have a higher incidence of early onset NIDDM $[69,70]$.

\section{PHARMACOTHERAPY OF OBESITY}

Obesity re sults from an imbalance be tween e nergy uptake and energy expenditure $[7,66,68]$. Obesity is a particularly challenging medical condition because of it s complex etiology (F ig. 3). The environmental fa ctors $\mathrm{c}$ an be modulated through behavioral changes such as healthy eating and physical a ctivity, wh ereas bi ological components a re much more dif ficult to a ddress [71]. The hi story of $t$ reatment of obesity is marked by li mited but long 1 asting s uccess, re bound re covery of we ight a fter c essation of $t$ reatment, and some therapeutic disasters. Cure of obe sity is rare and obesity is not a single entity. Still, palliation of obe sity re lated disorders remain a realistic clinical goal. Overweight patients exhibit symptoms of $\mathrm{t}$ he $\mathrm{m}$ etabolic syndrome that includes type 2 diabetes, hypertension, and dyslipidaemias [33]. Failure of diet and exercise in the long-term treatment of obesity is common and $\mathrm{c}$ reates an obvi ous $\mathrm{n}$ eed for concomitant pharmacotherapy. D rug tr eatment is r ecommended for subjects with a BMI more than $30 \mathrm{~kg} / \mathrm{m}^{2}$ and thus at medical risk from obesity, and if given at all, should be used only as an adjunct behavioral and lifestyle changes. Characterization of obesity - associated ge ne produc ts has re vealed ne w bi ochemical $p$ athways an molecular ta rgets for pharmacological i ntervention, w hich w ill li kely 1 ead t o ne w t reatments [71].

Anti-obesity d rugs can b e cl assified acco rding to their primary mechanism of ac tion on en ergy b alance. There are four ge neral classes of a nti-obesity drugs. The fi rst group comprises drugs, which suppress a ppetite through re ducing hunger pe rception, i ncreasing the f eeling of satiety, a nd reducing food intake by acting in the CNS. As a result these drugs facilitate compliance of the patient with caloric restriction. The second group - inhibitors of fat absorption - reduce energy intake through a peripheral, $g$ astrointestinal mechanism of a ction. The third group of drugs also acting peripherally $i$ ncreases $t$ hermogenesis $w$ ithout pla nned phys ical activity. The last group of drugs stimulates fat mobilization acting pe ripherally $\mathrm{t}$ o re duce fa $\mathrm{t} \mathrm{m}$ ass a $\mathrm{nd} /$ or de crease triglyceride synthesis without $\mathrm{p}$ lanned increases in phys ical activity or de crease in food i ntake. Im portantly, the be nefit of all four groups can be overcome by decreased voluntarily

\section{Strategy in the Treatment of Obesity}

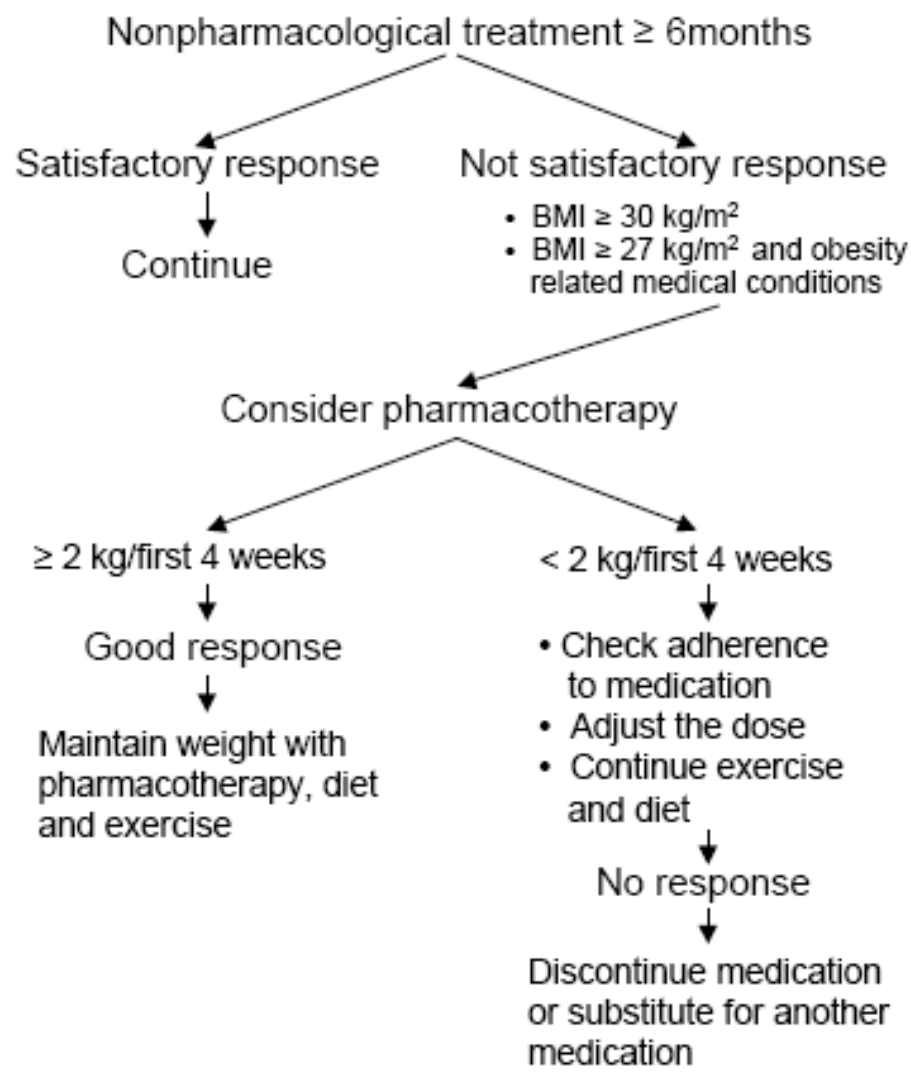

Fig. (3). Various approaches to treat obesity. Obesity is one of the more difficult to treat clinical conditions. The details of this flow-chart are discussed in details in the text. 
physical a ctivity or i ncreased consumption of c alorie dense food [71].

Nowadays the only drugs approved for use are a small set of c entrally a cting a ppetite $\mathrm{s}$ uppressors $\mathrm{t}$ hat re duce food intake by $\mathrm{m}$ odulating concentrations of $\mathrm{m}$ onoamine $\mathrm{n}$ eurotransmitters (s erotonin a nd/or nora drenaline) i $n t$ he bra in. The m odulation $\mathrm{c}$ an occur a t the level of neurotransmitter release and/or reuptake. Currently research focuses on identification of s pecific subtypes of s erotonin receptors that are involved in the regulation of food i ntake. Appetite suppressant medications generally produce an average weight loss of about $10 \%$ of initial body weight [71].

\section{Appetite Suppressants}

\section{Noradrenergic Agents}

Noradrenergic drugs available in the USA include phentermine, phe ndimetrazine, be nzphetamine, a nd di ethylpropion. They inhibit nora drenaline r euptake in the entral nervous system. Amphetamines are no longer recommended and not ap proved for $u$ se b ecause of the ad dicting potential of these agents. Benzphetamine and phendimetrazine belong to Schedule III according to the Drug Enforcement Administration (DEA). This means that these agents have moderate abuse a nd de pendency pot ential c ompared to S chedule I V agents, wh ich have low addictive po tential. Both $\mathrm{S}$ chedule III a nd Sc hedule I V agents ne ed pre scription due to their addictive properties $[72,73]$. Studies concerning safety and efficacy of these drugs show a consistent but moderate difference i $\mathrm{n} \mathrm{w}$ eight loss in $\mathrm{c}$ omparison $\mathrm{w}$ ith pla cebo. $\mathrm{S}$ ide effects of m edications that inhibit reuptake of nora drenaline include insomnia, euphoria, dry mouth, constipation, palpitations, and hypertension $[74,75]$. These medications are contraindicated in individuals with hypertension, advanced cardiovascular di sease, hype rthyroidism, gla ucoma, agitated states and history of drug abuse [72].

\section{Serotoninergic Agents}

Serotoninergic agents act by inhibiting reuptake of s erotonin, stimulating its re lease or bot $h$. One of these drugs, dexfenfluramine, was approved by the FDA in 1996 on the basis of its low risk/benefit ratio and extensive clinical experience in Europe, although some concerns had be en pre viously ra ised a bout the pos sible $r$ isk of pri mary pul monary hypertension and loss of s erotoninergic n eurons. Their efficacy w as close to the e fficacy of n oradrenergic d rugs [76]. But it was reported that dexfenfluramine alone or in combination $w$ ith o lder ge neration drug fe nfluramine or phe ntermine were associated with heart valvular disease and pulmonary hype rtension. Both fe nfluramine a nd de xfenfluramine were withdrawn from the global market in 1997 [72]. Selective serotonin-reuptake i nhibitors are a pproved for $\mathrm{i}$ ndications other than obesity, such as obsessive-compulsive disorders a nd de pression but s howed la ck of 1 ong-term e fficacy [77].

\section{Mixed Noradrenergic-Serotoninergic Agents}

Sibutramine, a $\mathrm{n}$ i nhibitor of bot $\mathrm{h}$ s erotonin a nd nore pinephrine r euptake, also we akly i nhibits dopa mine re uptake [72]. S ibutramine, phe ntermine, fe nfluramine, a nd s everal others (Fig. 4) are derivatives of L(-) ephedrine. Unlike fenfluramine and dexfenfluramine it does not cause release of serotonin and has not be en a ssociated with de velopment of cardiac valve dysfunction [78]. It is approved by the FDA for weight 1 oss a nd we ight $m$ aintenance in conjunction wi th a reduced - calorie diet [72]. It is given in a dose of $5-15 \mathrm{~m} \mathrm{~g}$ daily. Indi viduals receiving s ibutramine over $6 \mathrm{~m}$ onths pe riod and fol lowing a re duced-calorie die t us ually 1 ose 5-8 percent of their pre treatment weight. S ibutramine-induced weight lo ss is typically maintained $\mathrm{f}$ or o ne-year $\mathrm{p}$ eriod. Clinical trials up to two years have been completed and they show that although weight $w$ as regained during the second year o f tr eatment and f ollow-up, w eight lo ss a ttained $w$ as significantly greater in individuals treated for t wo complete years. Importantly, other metabolic factors related to weight loss a lso improve. These include improvement in lipid profile a nd hype ruricemia, as w ell a s gl ycemic c ontrol a nd plasma in sulin levels in patients with type 2 diabetes. However, be cause of bi g num ber of dr opouts in both the study and the c ontrol group, ge neralization i s probl ematic [79] . Side e ffects of sibutramine include increases in blood pressure a nd t achycardia, dry m outh, i nsomnia, he adache, a nd constipation [80]. Sibutramine is contraindicated in cases of uncontrolled hypertension, coronary artery disease, congestive h eart failure, arrhythmia, or s troke, s evere re nal or he patic dys function, na rrow-angle gla ucoma, a nd hi story of drug abuse [72].

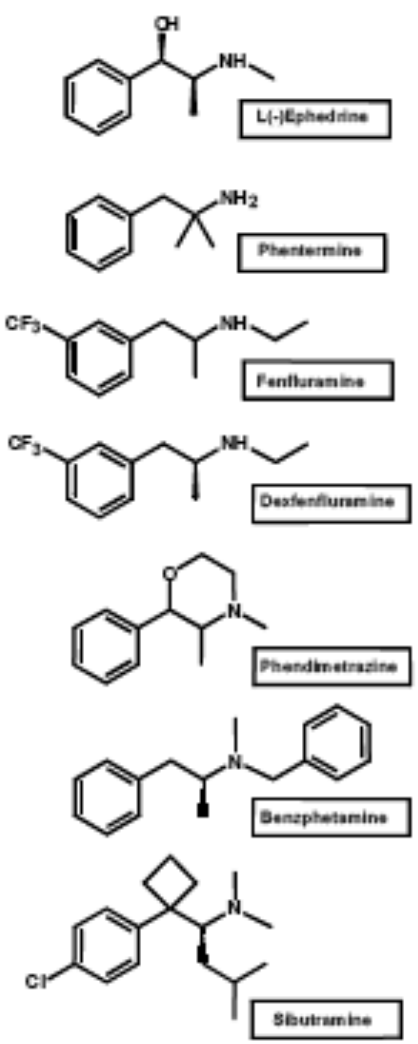

Fig. (4). Chemical structures of ephedrine derivatives, that have been tested as appetite suppressors. Ephedrine, an alkaloid originally ex tracted from Ephedra vulgaris, i s a sympathomimetic amine. I ts principal $\mathrm{m}$ echanism of ac tion re lies on $\mathrm{i}$ ts di rect and indirect a ctions on the a drenergic receptor s ystem, a part of the sympathetic n ervous system. The use of its d erivatives, especially sibutramine is discussed in the text. 


\section{Cannabinoid Receptor Antagonists}

Cannabinoids have s timulatory e ffect on a ppetite. Thus cannabinoid re ceptor be came $\mathrm{n}$ ew drug $\mathrm{t}$ arget for obe sity treatment. Cannabinoids act on central and peripheral receptors: cannabinoid receptors 1 (CB1) which are located in the brain as well as many peripheral tissues, and CB2 receptors which are primarily found in immune system cells. Cannabinoid re ceptor antagonists re duce food intake by $b$ locking central CB $1 \mathrm{r}$ eceptors. They probably a lso a ct pe ripherally by i ncreasing thermogenesis a nd thus e nergy e xpenditure. One of cannabinoid receptor antagonists rimonabant demonstrated c linical efficacy in the treatment of obesity and a lso improved $\mathrm{c}$ ardiovascular and $\mathrm{m}$ etabolic ri sk fa ctors [81]. It appears that $r$ imonabant re duces a dipose $m$ ass through e $n-$ hanced lipolysis, induction of enzymes of the beta-oxidation and TCA cycle, and increased energy expenditure. In a ddition to a transient reduction of food $\mathrm{c}$ onsumption, increases of both fatty acid oxidation and energy expenditure induced by the molecule summate leading to a s ustained w eight lo ss [82]. De spite these prom ising mechanisms of a ction, it $w$ as shown that weight loss following rimonabant and taranabant treatment $\mathrm{d}$ id $\mathrm{n}$ ot ex ceed th at a ttained $\mathrm{w}$ ith o ther cu rrently approved a nti-obesity $\mathrm{m}$ edications. In a ddition, pote ntially severe psychiatric adverse effects limit their clinical use [80, 81].

\section{Inhibitors of Fat Absorption}

Given the central role of die tary fat in obesity, a logical way to ach ieve an $\mathrm{d}$ maintain weight lo ss is to decrease the amount of fat available to be metabolized. Orlistat is the only FDA approved medication used for treatment of obe sity that reduces nutrient absorption. Orlistat belong to a class of antiobesity drugs that acts directly and specifically at the site of fat breakdown in the lumen of small intestine [80, 83]. It acts by binding to gastrointestinal lipases in the lumen of bowe1, preventing hydrol ysis of $t$ riglycerides (di etary fa $t$ ) into a bsorbable mono-acylglycerols and fre e fa tty a cids (F ig. 5). The medication taken up to one hour after meal will result in excretion in the stool of one third of di etary fat ingested. In double blind, placebo-controlled study, orlistat had moderate efficacy for we ight loss in adults (reduction by 9 pe rcent of pre-intervention weight in comparison to 5.8 percent among those who $t$ ook pl acebo) [84]. Orl istat s lowed the ra te of weight regain during a second year of use. Orlistat has additional $b$ eneficial effects, $\mathrm{s}$ uch as moderate $\mathrm{d}$ ecrease in d iastolic bl ood pre ssure, i n i nsulin 1 evel, re duction i n t otal cholesterol and low-density lipoprotein levels, improvement in glycosylated hemoglobin and decreased need for sulfonylurea drugs in patients with type 2 di abetes [85]. Systemic absorption of orl istat is negligible and the potential for $\mathrm{s} y \mathrm{ys}-$ temic ad verse ev ents th us s eems to b e s mall. S ide e ffects include flatulence with discharge, fecal urgency, fecal incontinence, steatorrhoea, oily spotting, and increased frequency defecation [83]. Orl istat a lso de creases a bsorption of fa tsoluble vitamins, mainly vitamin D a nd vitamin $\mathrm{K}$ [86]. As vitamin $\mathrm{K}$ absorption may be decreased, warfarin anticoagulation may be potentiated during orlistat therapy [87]. Therefore, patients receiving warfarin who start Orlistat need close monitoring of $t$ heir IN R. Re duction i $n t$ he a bsorption of amiodarone and cyclosporine is another potential drug inter- action of or listat $[88,89]$. A lthough absolute concentrations of vi tamins $\mathrm{D}, \mathrm{E}$, a nd $\beta$-carotene de creased duri ng orl istat treatment, th e co ncentrations $r$ emained $w$ ithin the $n$ ormal range and on ly few individuals $w$ ith 1 ow $v$ alues $n$ eed supplementation [83]. The latter side effect can be counteracted by administration of a multivitamin at least two hours before or after the dose of orlistat. These results support the potential of orlistat for long-term management of obese patients in combination with an appropriate diet [86].

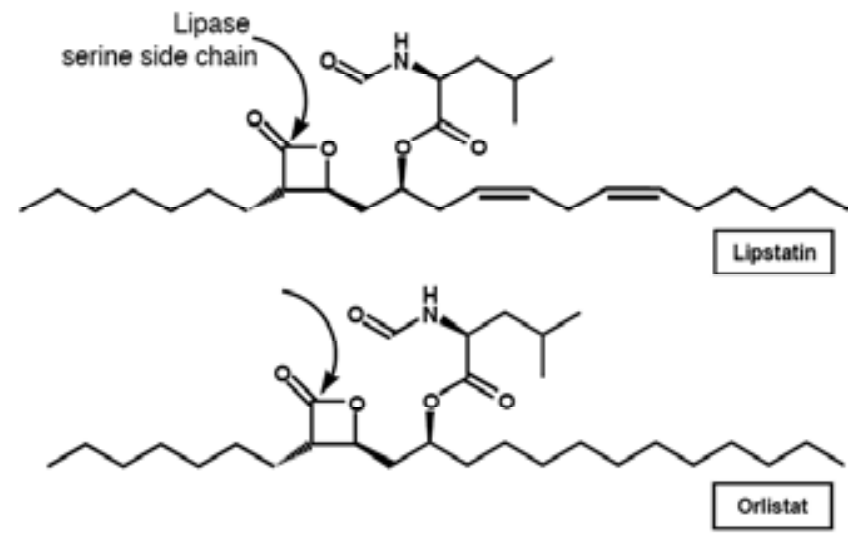

Fig. (5). L ipase inhibitors lipstatin and orl istat. Orlistat (Tetrahydrolipstatin) is a stable derivative of the microbial product lipstatin (i solated from Streptomyces toxytricini). O rlistat and L ipstatin act by covalent attachment to a serine side chain. The site of attachment (the lactame ring of Orlistat or Lipstatin) is indicated by an a rrow. The covalent attachment results in the inhibition of the lipase.

Other steps required for a bsorption of di etary fat, wh ich involves pro teins, might re present prom ising drug ta rgets. After hydrolysis, free fatty acids cross the membrane of the epithelial c ell lin ing the in testinal w all. FATP4, a n ewly discovered fre e fa tty acid $t$ ransporter, $m$ ight ha ve a $m$ ajor role in this process. But its therapeutic value could be limited if free fa tty acids are mainly transported passively [90]. Inside ep ithelial c ell free fatty a cids are tr ansferred to the en doplasmic re ticulum fa tty-acid-binding prot eins ( FABPs). Possible inhibition of FABPs is questionable since the highest co ncentration of FABPs is in the en terocyte cy tosol. Acyl-CoA is then tr ansferred to 2 -monoacylglycerol to $\mathrm{re}$ synthesize triglycerides. Acyl-CoA: diacylglycerol acyltransferase (DGAT) is the key enzyme in triglyceride re-synthesis and its inhibition could represent a valid new strategy in the treatment of obe sity. However, lack of DG AT in mice does not prevent $f$ at absorption, thus o ther $\mathrm{p}$ athways for triglyceride synthesis must exist [91].

\section{Stimulators of Thermogenesis}

Adaptive th ermogenesis co nfers the ab ility to ad apt to prolonged e xposure to cold (non-s hivering thermogenesis) and overfeeding (diet-induced thermogenesis). The biogenesis of $\mathrm{m}$ itochondria and the induction of s pecific mitochondrial prote ins that control the e fficiency of oxi dative phos phorylation are the key cellular processes of a daptive thermogenesis [92]. T hyroid horm one and nora drenaline re leased from $\mathrm{s}$ ympathetic ne rve e ndings ha ve a profoun $\mathrm{d}$ impact on adaptive thermogenesis. Thyroid hormone is not a viable pharmacological anti-obesity approach, since it causes 
loss of lean body mass and mobilizes calcium from the bone $[93,94]$. In c ontrary, $\beta_{3}$ s elective adrenergic a gonists $h$ ave anti-obesity and anti-diabetic e ffects in rodents a nd induce brown adipose tissue hypertrophy also in dogs and monkeys $[95,96]$. Howe ver, it is s till c ontroversial whe ther $\beta_{3}$ AR agonists will have a relevant impact on energy expenditure in humans. $\mathrm{H}$ ighly s elective, ora lly bi o-available $\beta_{3}$ AR a gonists are now in clinical trials (Table 1) [97, 98].

In adult humans, the major thermogenic tissue is skeletal muscle that, in non-obe se individuals, c omprises about 40 percent of body weight and accounts for $20-30$ percent of the total oxyge $\mathrm{n}$ c onsumption at re st. U CP-1 i s uni que a mong uncoupling prot eins, it ha s pr imary rol e in nora drenaline dependent adaptive non-shivering thermogenesis and consequent $m$ etabolic inefficiency. Its expression is increased in cold exposure as well as overfeeding and decreased in fasting and states of genetic obesity [99]. Proteins highly similar to $\mathrm{UCP}-1$ have $b$ een r ecently identified. These proteins are also e xpressed in $t$ issues o ther $t$ han brown fa t. U CP-2 is ubiquitously distributed in the body, so because of high likelihood for unde sirable side effects, it is no $t$ an appropriate target for anti-obesity drug. UCP-3 is primarily expressed in skeletal muscle in humans, its ex pression is co rrelated with

Table 1. The Pharmacologic Options of Obesity Treatment

\begin{tabular}{|c|c|c|c|c|c|}
\hline Groups & $\begin{array}{l}\text { Mechanism of } \\
\text { Action }\end{array}$ & Examples I & ndications & Contraindications & Adverse Effects \\
\hline \multirow[t]{3}{*}{$\begin{array}{l}\text { Appetite } \\
\text { Suppressors }\end{array}$} & $\begin{array}{l}\text { Inhibit norepi- } \\
\text { nephrine release } \\
\text { in CNS }\end{array}$ & $\begin{array}{l}\text { Benzphetamine } \\
\text { Phendimetazine }\end{array}$ & $\begin{array}{l}\text { Obesity, weight } \\
\text { maintenance }\end{array}$ & $\begin{array}{l}\text { Hypertension, hyperthyroidism, } \\
\text { advance cardiovascular disease, } \\
\text { glaucoma, agitated states, history of } \\
\text { drug abuse [69] }\end{array}$ & $\begin{array}{l}\text { Insomnia, euphoria, dry } \\
\text { mouth, constipation, } \\
\text { palpitations, hypertension, } \\
\text { moderate addictive poten- } \\
\text { tial [70-72] }\end{array}$ \\
\hline & $\begin{array}{l}\text { Inhibit reuptake } \\
\text { of serotonin } \\
\text { and/or its release }\end{array}$ & $\begin{array}{l}\text { Dexfenfluramine } \\
\text { Fenfluramine }\end{array}$ & $\begin{array}{l}\text { Obesity, weight } \\
\text { maintenance, obses- } \\
\text { sive-compulsive } \\
\text { disorder, depression } \\
{[74]}\end{array}$ & & $\begin{array}{l}\text { Heart valvular disease, } \\
\text { pulmonary hypertension } \\
{[69,74]}\end{array}$ \\
\hline & $\begin{array}{l}\text { Inhibit norepi- } \\
\text { nephrine and } \\
\text { serotonin reup- } \\
\text { take in CNS }\end{array}$ & $\begin{array}{l}\text { Sibutramine (Me- } \\
\text { ridia, Reductil) }\end{array}$ & $\begin{array}{l}\text { Obesity, weight } \\
\text { maintenance [69] }\end{array}$ & $\begin{array}{l}\text { Uncontrolled hypertension, coronary } \\
\text { artery disease, congestive heart } \\
\text { failure, arrhythmia, stroke, severe } \\
\text { renal/hepatic dysfunction, glaucoma, } \\
\text { history of drug abuse [69] }\end{array}$ & $\begin{array}{l}\text { Hypertension, tachycar- } \\
\text { dia, dry mouth, insomnia, } \\
\text { headache, constipation } \\
{[77,138]}\end{array}$ \\
\hline $\begin{array}{l}\text { Inhibitors of } \\
\text { fat absorption }\end{array}$ & $\begin{array}{l}\text { Bind gastrointes- } \\
\text { tinal lipases }\end{array}$ & Orlistat (Xenical) & $\begin{array}{l}\text { Obesity, weight } \\
\text { maintenance [81] }\end{array}$ & & $\begin{array}{l}\text { Gastrointestinal side } \\
\text { effects, decreased absorp- } \\
\text { tion of fat-soluble vita- } \\
\text { mins }[80,83-86]\end{array}$ \\
\hline \multicolumn{6}{|l|}{$\begin{array}{l}\text { New and } \\
\text { investigational } \\
\text { drugs }\end{array}$} \\
\hline $\begin{array}{l}\text { Stimulators of } \\
\text { thermogenesis }\end{array}$ & $\beta_{3} \mathrm{AR}$ agonists & $\begin{array}{l}\text { SWR-0342SA [92- } \\
\text { 94] }\end{array}$ & Obesity and diabetes & & \\
\hline $\begin{array}{l}\text { Stimulators of } \\
\text { fat mobiliza- } \\
\text { tion }\end{array}$ & $\begin{array}{l}\text { Stimulate the } \\
\text { formation of } \\
\text { brown adipose } \\
\text { tissue }\end{array}$ & $\begin{array}{l}\text { PPAR } \gamma \text { ligands } \\
\text { PCG1 [128] }\end{array}$ & $\begin{array}{l}\text { Obesity and diabetes } \\
\text { [99] }\end{array}$ & & \\
\hline $\begin{array}{l}\text { Cannabinoid } \\
\text { receptor } 1 \\
\text { antagonists }\end{array}$ & $\begin{array}{l}\text { Suppress appe- } \\
\text { tite, increase } \\
\text { thermogenesis }\end{array}$ & $\begin{array}{l}\text { Rimonabant } \\
\text { (Acomplia) } \\
\text { Taranabant }\end{array}$ & Obesity & & $\begin{array}{l}\text { Severe psychiatric mood } \\
\text { related disorders [77-79] }\end{array}$ \\
\hline \multirow[t]{4}{*}{ Other drugs } & $\begin{array}{l}\text { Increase energy } \\
\text { expenditure }\end{array}$ & $\begin{array}{l}\text { Selective inhibitors } \\
\text { of PTP1B [124, } \\
125]\end{array}$ & Obesity and diabetes & & \\
\hline & $\begin{array}{l}\text { Activate } 2 \mathrm{C} \\
\text { serotonin recep- } \\
\text { tor }\end{array}$ & BVT $933[8]$ & Obesity & & \\
\hline & $\begin{array}{l}\text { Specifically } \\
\text { inhibits fatty acid } \\
\text { synthase }\end{array}$ & C75 [8] & Obesity & & \\
\hline & $\begin{array}{l}\text { Activates leptin } \\
\text { pathway, inhibits } \\
\text { activity of acetyl } \\
\text { coenzyme A } \\
\text { carboxylase }\end{array}$ & $\begin{array}{l}\text { Axokine } \\
\text { (Ciliary Neurotro- } \\
\text { phic } \\
\text { Factor) }[102]\end{array}$ & Obesity & & \\
\hline
\end{tabular}


energy expenditure in P ima Indians, and mutations in gene encoding U CP-3 w ere identified in some individuals $\mathrm{w}$ ith severe obe sity and NIDDM [100]. So its stimulation could provide safer $m$ echanism to increase th ermogenesis in the whole bod $\mathrm{y}$. T herefore, a pha rmacological s timulation of UCP-3 activity could result in beneficial effects against obesity and NIDDM [101].

\section{Stimulators of F at Mobilization, Modulators of F at Stor- age}

Another pos sible a nti-obesity a pproach c ould be $t$ he stimulation of brown a dipose tissue formation, either by $d e$ novo recruitment from pre-adipocytes or by inter-conversion of $w$ hite adipocytes. P PAR $\gamma$ li gands a re ve ry effective in inducing of $U$ CP 1 expression in brown but not $\mathrm{i} n$ white adipocytes, which indicates the existence of a brown adipose tissue $\mathrm{s}$ pecific co factor. $\mathrm{S}$ uch a cofactor, P PAR $\gamma$ co activator-1 (PGC-1) is strongly induced by cold [102]. PCG1 allows P PAR $\gamma$ to function in the specific context of thermogenesis by a llowing the expression of UCP 1 a nd by fa voring multiplication of mitochondria. PGC-1 could promote the development of the brown a dipocyte phenotype. Thus, it seems that PGC-1 plays a key role in transcriptional program of a daptive thermogenesis and this finding could stimulate development of novel anti-obesity drugs [102].

\section{Calorie Restriction Mimetics}

Perhaps th e m ost studied ca lorie restriction $m$ imetics $(\mathrm{CRM})$ is resveratrol, a plant-derived polyphenol produc ed in a response to attacking pathogen. The important source of this compound is: root of J apanese knot weed (Fallopia japonica), skin of red grapes, red wine, peanuts, and mulberry. This polyphenol has been shown to retard the aging process in ye ast, ne matodes and fruit flies by $70 \%$. The molecular pathway mediating $\mathrm{c}$ alorie $\mathrm{r}$ estriction in y east $\mathrm{r}$ equires a ctivation of the silent information regulator 2 (Sir2) gene which is im plicated i $\mathrm{n} t$ he li fespan e xtension [103, 104]. T he mechanism of action of resveratrol in lifespan determination is $b$ ased on the ability to $\mathrm{m}$ imic the $\mathrm{c}$ alorie restriction in a Sir2-dependent $\mathrm{m}$ anner. The $\mathrm{m}$ ammalian hom ologs of $\mathrm{S}$ ir2 are SIRT1-7 and are expressed in different compartments of the cell such a s cytoplasm, nucleus and mitochondria. It is believed that $r$ esveratrol-dependent a ctivation of S IRTs in human re sults in re gulation of va rious phys iological $p$ athways i ncluding fa $\mathrm{t} \mathrm{m}$ obilization [105], i nsulin s ecretion [106] gl uconeogenesis [107]. Recent study has s hown that increased dose of resveratrol allowed obese $m$ ice to $r$ emain on hi gh-calorie die $\mathrm{t}$ wit hout $\mathrm{s}$ hortening lifespan [108] . Moreover, resveratrol intake protects against radiation [109], development of c ancer, c ardiovascular di sorders [110-112] as well as is utilized in treatment of metabolic disorders such as diabetes 2 [113]. Besides the red wine, resveratrol is easily accessible in a supplement form.

Another very important group of CRM are insulin sensitizers wit $\mathrm{h} \mathrm{m}$ etformin at $\mathrm{t}$ he fore front. $\mathrm{T}$ his drug is ve ry widely us ed against pre dominantly obe sity-driven type 2 diabetes and cardiovascular diseases [114, 115]. Metformin increases s ensitivity of in sulin $r$ eceptors o $n$th e $s$ urface of muscle and fat cells but does not increase secretion of insulin. Additionally, metformin is implicated in suppression of endogenous gl ucose produc tion [116] and its inhibitory e ffect depends on the AMP-activated prote in kinase (AMPK) [117]. Moreover, it has been shown that 2 months treatment with metformin $h$ as a significant im pact on $\mathrm{m}$ imicking the outcome of long-term calorie restriction in mice [118].

Another group of CRM used in treatment of obe sity and type 2 di abetes is thiazolidinediones that includes ros iglitazone and pi oglitazone [119]. These two drugs increase the sensitivity of the cell to insulin by act ivation of the nuclear receptor P PAR $\gamma$ (s ee a lso pre vious pa ragraph). Howe ver, resent $\mathrm{s}$ tudies link thiazolidinediones with increased risk of death from cardiovascular causes [120].

Fourth CRM involved in glucose metabolism is 2-deoxy$\mathrm{D}$-glucose. Th is m olecule i s ab le to k eep cer tain 1 evel o f plasma $g$ lucose wit hout $r$ educing food $c$ onsumption. Long intake of 2-de oxy-D-glucose ha s ve ry 1 ittle e ffect on bod y weight and consumption but $\mathrm{c}$ an lower blood pre ssure s ignificantly $[119,121]$.

Previously discussed leptin could also be included in the group of drugs re gulating body we ight a nd food i ntake. Leptin $m$ aintains it s phys iologic a ctions through e ffects o $n$ hypothalamic centers $r$ esponsible for hunge $r$ a nd fe eding [122]. Howe ver its long-term intake re sults in le ptin re sistance, of wh ich mediator re mains unknown. T he w ay to solve this issue is direct leptin gene transfer into hypothalamus u sing r ecombinant ad eno-associated $v$ irus. S uch in jection of recombinant adeno-associated virus-leptin is effective in 1 owering le vel of fa $\mathrm{t}$, i nsulin, triglycerides a nd pre vents from weight gain [123].

\section{Other Investigational and New Drugs}

The major leaps towards the development of more effective anti-obesity drugs have actually lead into a better understanding of fa $t \mathrm{~m}$ etabolism. In pa rticular the di scovery and cloning of the a dipocyte-derived horm one leptin and its receptor $p$ roved to $b$ e $m$ ajor $b$ reakthroughs. L eptin re flects the lipid content of the total body of a non-fasting person. In a few children, s evere, e arly-onset obe sity has be en a ssociated wit $\mathrm{h}$ i nability $\mathrm{t}$ o produc e func tional le ptin prot ein. Treatment of a leptin-deficient $g$ irl with recombinant human leptin induced a dramatic reduction in body weight $(16.4 \mathrm{~kg})$ and changes in body composition [124]. In case of treatment of a dults who ha ve norm al le ptin le vels $w$ ith re combinant leptin re sults we re much less prom ising (loss of 7. 1 to 8.5 $\mathrm{kg}$ ). Actually, those patients have a lot of endogenous leptin and are leptin resistant. Problems related to formulation were pain a nd i nduration a $\mathrm{t}$ i njection $\mathrm{s}$ ite. Ongoi ng s tudies a re evaluating $t$ he bot $h$ dif ferent form ulations of 1 eptin a nd leptin-replacement therapy during low-calorie dieting [125].

A new drug, which is now in phase III c linical trials, is 'Axokine'. This is an engineered version of ciliary neurotrophic factor. It was originally developed for the treatment of amyotrophic lateral sclerosis. Axokine activates leptin pathway, in addition it does not cause rebound weight gain even in leptin resistant model of obesity because it bypasses compensatory adjustments ensuring the maintenance of body fa $t$ homeostasis. A s a r esult th e p atient is s atisfied $w$ ith 1 ess food, $\mathrm{s}$ o $t$ he pe rson $\mathrm{w}$ ill $\mathrm{b}$ e $\mathrm{p}$ ractically $\mathrm{d}$ ieting. A xokine works by hyper-activating the leptin pathway, and turning on 
satiety signal. It was demonstrated that leptin, in addition to its role as a satiety factor, also inhibits activity of acetyl coenzyme A c arboxylase, $t$ hus preventing accumulation of lipids i n non-a dipose ti ssues a nd s timulating oxi dation of fatty acids and uptake of glucose [126].

The protein-tyrosine phosphatase (PTP1B) is an other interesting ta rget $f$ or an ti-obesity $d$ rugs. $R e$ cent $r$ esearch showed that $\mathrm{PTP} 1 \mathrm{~B}$ regulates leptin signal transduction, in a way that lowered levels of P TP1B increase energy expenditure and vice versa. In addition it negatively regulates insulin signaling [127]. The problem has been in designing a molecule that s pecifically in hibits $P T P 1 B$. One $\mathrm{r}$ esearch group developed an antisense o ligonucleotide to s electively b lock $P T P 1 B$ e xpression. This antisense oli gonucleotide norm alized bl ood gl ucose level in dia betic and obe se $\mathrm{m}$ ice a nd lowered serum tr iglyceride an d cholesterol co ncentrations [128]. Antisense technology has an advantage of be ing able to block the production of prot ein rather than just inhibiting it once it is produced.

BVT.933 i s a s elective s erotonin re uptake inhibitor (SSRI), which is now in phase II clinical trials. It activates specifically onl y one, $\mathrm{t}$ he $2 \mathrm{C}$ s erotonin $\mathrm{r}$ eceptor. $\mathrm{P}$ atients treated wit h BVT.933 achieved s tatistically a nd c linically significant $w$ eight lo ss co mpared $w$ ith $p$ lacebo. F atty a cid synthase has also recently received recently serious attention as a new target of anti-obesity treatment [8]. Specific inhibitor of fa tty a cid s ynthase, C75, i n obe se mice s uppresses food i ntake, re duces body we ight, a nd norm alizes obe sityassociated hyperglycemia and hyperinsulinaemia.

PPAR $\alpha$ a nd PPAR $\gamma$ receptors ( which ar e d istributed widely in tissues and cell types) constitute multiple therapeutic ta rgets for $t$ reatment of dia betes a nd obe sity. Ide ally, drugs pos sessing bot $\mathrm{h}$ P PAR $\alpha / \gamma$ a gonist potencies a re expected to $p$ rovide th e b est $m$ eans to $d$ ecrease $m$ ultiple $r$ isk factors for $m$ orbidity and mortality existing in diabetic patients by a cting on fa $t \mathrm{c}$ ells and liver. PPAR $\gamma$ is mainly ex pressed in adipose tissue; so metabolic effects are thought to result from direct action on the adipose tissue and secondary impact in liver and skeletal muscle. The beneficial effects of PPAR $\gamma$ agonists on m uscle, liver, and vessels a re mediated by their ability to improve insulin-mediated uptake and metabolism of gl ucose and NEFA in the adipocytes, to induce the production of a diponectin, and to re duce production of adipocyte-derived fa ctors 1 eading t o i nsulin re sistance (re sistin, TNF and inflammatory molecules) [129, 130]. It has been a lso d emonstrated that experimental drugs $w$ ith dua 1 activation of P PAR $\alpha$ and $\gamma \mathrm{h}$ ave $\mathrm{p}$ otential $\mathrm{f}$ or $\mathrm{u}$ se in the treatment of various aspects of metabolic dysfunction in type 2 di abetes that i nclude dys lipidemia, hype rglycemia, a nd hyperinsulinaemia [131].

In view of the multiple metabolic and vascular effects of adiponectin, it is pos sible that improvement in $\mathrm{m}$ etabolic disturbances of $\mathrm{m}$ etabolic syndrome a tributable to the e ffects of P PAR $\gamma$ a gonists could be re lated to their action on adiponectin production and release by fat tissue [33]. Novel treatments are needed to help those millions of people suffering from obe sity, especially the dra matically ris ing number of ove rweight children who a re at ris $\mathrm{k}$ of 1 ifelong di abetes and the accompanying risk of heart disease and disability.

\section{STRATEGIES F OR U SE O F MEDICATIONS IN T HE TREATMENT OF OBESITY}

Obesity i s a chronic c ondition, s o pharmacotherapy should be initiated with the knowledge that long-term use of pharmacological ag ents will be most lik ely needed (Fig. 3). Therefore, the pos sible ri sks of 1 ong-term m edical therapy must be weighed against potential improvements in the patient's $r$ isk of obe sity-related di sease. In ge neral, the pharmacotherapy should be initiated only in patients whose BMI is at least 30 in the absence of obesity-related medical conditions or BM I of a $\mathrm{t}$ le ast $27 \mathrm{i} \mathrm{n}$ the pre sence of $\mathrm{s}$ uch conditions. Since efficacy of approved drugs is similar in different groups of a nti-obesity drugs, usually the choice is empirical with $\mathrm{c}$ onsideration of underlying $\mathrm{m}$ edical $\mathrm{c}$ onditions and contraindications. Non-pharmacological treatment should be tried for $\mathrm{s}$ ix $\mathrm{m}$ onths a nd $\mathrm{w}$ eight-loss a gents $\mathrm{c}$ onsidered if reduction in we ight is unsatisfactory. B ehavioral modifications combined with pharmacological approach may result in better outcome. In $\mathrm{p}$ atients w ithout weight loss of at least 2 $\mathrm{kg}$ duri ng the fi rst four we eks of $\mathrm{t}$ reatment, a dherence to medication, diet, and exercise should be reassessed and possibly the dos e should be a djusted. If there continues to b e minimal re sponse to the $\mathrm{m}$ edication, the clinician $\mathrm{s}$ hould consider $\mathrm{d}$ iscontinuing or $\mathrm{s}$ ubstituting another m edication. Major areas of prom ise for pha rmacotherapy are in enhancing we ight $m$ aintenance in those who ha ve lost w eight by variety of $m$ ethods [74]. S ince almost all non-s urgical obesity tr eatments 1 ead to w eight lo ss for the first four to $\mathrm{s}$ ix months fol lowed by re gain, pha rmacotherapy $\mathrm{c}$ an be instituted for e nhancement of we ight loss during the pe riod of active w eight lo ss or to prevent w eight r egain [78]. At present, c ombinations of anti-obesity drugs a re not re commended outside clinical trials [74]. Treatment in children and adolescents can be co nsidered if their BMI is in the $95^{\text {th }}$ percentile or $h$ igher or i f they s uffer from ob esity-related condition, whi ch $\mathrm{c}$ an be treated by we ight re duction. T he safety and efficacy of orl istat and sibutramine are not determined for children and adolescents, $\mathrm{s}$ ince no s tandardized clinical trials have been conducted so far for this population [132]. $\mathrm{F}$ urther $\mathrm{s}$ tudies are $\mathrm{n}$ eeded $\mathrm{b}$ efore pha rmacotherapy outside clinical trials $\mathrm{c}$ an be recommended for younge $\mathrm{r}$ patients [72].

\section{CLOSING REMARKS}

Obesity can be viewed as a disturbance of complex homeostatic $m$ echanisms controlling energy $b$ alance in the body. $\mathrm{T}$ he ve ry c omplicated, $\mathrm{m}$ ulti-pathway re gulation of body mass on one side, and the effects of obesity on fertility, (auto)immunity, cardiovascular $\mathrm{d}$ isease, non-a lcoholic fa tty liver dis ease, endocrine problems, c ancer development, diabetes and other diseases show the inter-connected nature of various body functions. For example, the PI3-K/Akt pathway that is implicated in cell survival and proliferation, branches through the m TOR-signaling cascade into metabolism regulation [133-136]. T he $\mathrm{m}$ TOR pa thway $\mathrm{s}$ timulates prote in synthesis and hence cell growth and hypertrophy in response to growt $h$ fa ctors a nd a mino a cids [17]. T hus a nti-obesity pharmacotherapy $\mathrm{w}$ ith a $\mathrm{n}$ im pact on $\mathrm{t}$ hese pa thways $\mathrm{m}$ ay have potential to induce a neuploidy and tumorigenic de differentiation of normal cells. 
Currently approved prescription medications, even moderate in their efficacy, c an help carefully s elected obese patients to lo se $w$ eight or to $r$ educe the $r$ ate o f $r$ egain. The safety and e fficacy of $m$ any anti-obesity drugs be yond two years have not yet been established and long-term effects on morbidity and mortality are a lso to b e d etermined. Recent advancements in s tem cell $\mathrm{r}$ esearch a $\mathrm{t}$ least th eoretically open new possibilities for obesity treatment, like for example switching (brown) fat $\mathrm{c}$ ells i nto $\mathrm{m}$ uscle c ells [137]. Still, primary m eans in treatment of obe sity a re be havioral interventions, which include appropriate diet and physical activity. Finally, it should be emphasized that the ultimate therapeutic goal in the treatment of obesity is not weight loss, but rather a reduction in morbidity and mortality from associated complications. S uch c onsiderations woul d fa vor ne w a ntiobesity drugs that not on ly a ffect $w$ eight $\mathrm{c}$ ontrol but a lso improve metabolic and cardiovascular function.

\section{ACKNOWLEDGEMENTS}

S.P. thankfully a cknowledges the s upport from MHRC. M.L. thankfully a cknowledges support through CFI-Canada Research Ch air program, M HRC-, CI HR, and M ICHfounded programs.

\section{ABBREVIATIONS}

$\mathrm{AR}=$

ALBP

ANP

AMPK

ANS

BMI

$\mathrm{cAMP}=$

CB1

CCK

cGMP $=$

$\mathrm{CNS}$

$\mathrm{CRF}=$

CRM

DEA $=$

DGAT $=$

FDA

FATP $=$

FABPs $=$

$\mathrm{GH}=$

HSL

$\mathrm{IL}=$

iNOS

$\mathrm{Jak} / \mathrm{Stat}$
Adrenergic Receptor

$=$ Adipocytes Lipid Binding Protein

$=$ Atrial Natriuretic Peptide

= Adenosine $\mathrm{M}$ onophosphate Activated Protein Kinase

$=$ Autonomic Nervous System

$=$ Body Mass Index

Cyclic Adenosine Monophosphate

$=$ Cannabinoid receptor 1

$=$ Cholecystokinin

Cyclic Guanosine Monophosphate

$=$ Central Nervous System

Corticotropin Releasing Factor

$=$ calorie restriction mimetics

Drug Enforcement Administration

Diacylglycerol Acyl Transferase

$=$ Food \& Drug Administration

Free Fatty Acid Transporter

Fatty Acid Binding Proteins

Growth Hormone

$=$ Hormone Sensitive Lipase

Interleukin

$=$ Inducible Nitric Oxide Synthase

$=$ Janus Ki nase-Signal Transducer a nd Activator of Transcription

\begin{tabular}{|c|c|c|}
\hline $\mathrm{MF}=$ & & Lipid Mobilizing Factor \\
\hline MSH & $=$ & Melanocyte Stimulating Hormone \\
\hline $\mathrm{MCP}-1=$ & & Monocyte Chemotactic Protein-1 \\
\hline mTOR & $=$ & Mammalian target of rapamycin \\
\hline $\mathrm{P} 4=$ & & Neuropeptide 4 \\
\hline $\mathrm{EFA}=$ & & Non-Esterified Fatty Acid \\
\hline $\mathrm{JO}=$ & & Nitric Oxide \\
\hline NIDDM & $=$ & Non-Insulin Dependent Diabetes Mellitus \\
\hline $\mathrm{B}-\mathrm{R}=$ & & Leptin Receptor \\
\hline DE-3B & $=$ & Type 3b Phosphodiesterase \\
\hline $\mathrm{PKA}=$ & & Protein Kinase A \\
\hline $\mathrm{PKB}=$ & & Protein Kinase B \\
\hline PAI-1 & $=$ & Plasminogen Activator Inhibitor 1 \\
\hline $\operatorname{PAR} \alpha \& \gamma$ & $=$ & $\begin{array}{l}\text { Peroxisome } \mathrm{P} \text { roliferator Ac tivated } \mathrm{Re} \text { - } \\
\text { ceptor } \alpha \& \gamma\end{array}$ \\
\hline PGC-1 & $=$ & $\begin{array}{l}\text { Peroxisome } \mathrm{P} \text { roliferator Ac tivated } \mathrm{Re}- \\
\text { ceptor- } \gamma \text { Co-Activator- } 1\end{array}$ \\
\hline PTP1B = & & Protein-Tyrosine Phosphatase-1B \\
\hline NS & $=$ & Sympathetic Nervous System \\
\hline SRI & $=$ & Selective Serotonin Reuptake Inhibitor \\
\hline$A G=$ & & Triacyl-Glycerol \\
\hline $\mathrm{F}$ & $=$ & Tumor Necrosis Factor $\alpha$ \\
\hline $\begin{array}{l}\text { JPC-1, = } \\
\text { JPC-2, UPC-3 }\end{array}$ & & Uncoupling Proteins \\
\hline $\mathrm{J}=$ & & Zinc- $\alpha_{2}$-Glycoprotein. \\
\hline
\end{tabular}

\section{REFERENCES}

[1] Ogden, C. L.; Yanovski, S .Z.; Ca rroll, M .D.; Flegal, K .M. Th e epidemiology of obesity. Gastroenterology, 2007, 132, 2087-102.

[2] Weisell, R.C. B ody mass index as an i ndicator of obes ity. Asia. Pac. J. Clin. Nutr., 2002, 11. Suppl. 8, S681-4.

[3] (2000). O besity: p reventing a nd $\mathrm{m}$ anaging th e g lobal e pidemic. Report of a WHO consultation, Volume 894.

[4] Stevens, J.; McClain, J.E.; Truesdale, K.P. Selection of measures in epidemiologic studies of the consequences of obesity. Int. J. Obes. (Lond), 2008, 32. Suppl. 3, S60-6.

[5] Krotkiewski, M.; B jorntorp, P.; S jostrom, L.; S mith, U. Impact of obesity on metabolism in men and women. Importance of regional adipose tissue distribution. J. Clin. Invest., 1983, 72, 1150-62.

[6] Hedley, A.A.; Ogden, C.L.; Johnson, C.L.; Ca rroll, M.D.; Curtin, L.R.; F legal, K.M. P revalence of ov erweight and ob esity amo ng US children, adolescents, and adults, 1999-2002. JAMA, 2004, 291, 2847-50.

[7] O'Rahilly, S.; F arooqi, I.S. G enetics of o besity. Philos. Trans. $R$ Soc. Lond. B. Biol. Sci., 2006, 361, 1095-1105.

[8] Chiesi, M .; H uppertz, C .; H ofbauer, K .G. P harmacotherapy of obesity: ta rgets a nd perspectives. Trends. Pharmacol. Sci., 2001, 22, 247-54.

[9] Berthoud, H.R. Multiple neural systems controlling food intake and body weight. Neurosci. Biobehav. Rev., 2002, 26, 393-428.

[10] Berthoud, H .R.; M orrison, C . Th e b rain, a ppetite, a nd o besity. Annu. Rev. Psychol., 2008, 59, 55-92.

[11] Friedman, J.M. The alphabet of weight control. Nature, 1997, 385, 119-20.

[12] Strosberg, A.D.; I ssad, T. The involvement of 1 eptin in hum ans revealed by mutations in leptin and leptin receptor genes. Trends 
Pharmacol. Sci., 1999, 20, 227-30.

[13] G. F rühbeck, S.A.J.A.M.P. Leptin: phys iology and pat hophysiology. Clinical. Physiology, 1998, 18, 399-419.

[14] Diamond, F.B., Jr.; Eichler, D.C. Leptin and the adipocyte endocrine system. Crit. Rev. Clin. Lab. Sci., 2002, 39, 499-525.

[15] Bates, S .H.; Stearns, W.H.; D undon, T.A.; S chubert, M .; Tso, A.W.; Wang, Y.; Banks, A.S.; Lavery, H.J.; Haq, A.K.; MaratosFlier, E. ; N eel, B.G.; Schwartz, M.W.; Myers, M.G., J r. S TAT3 signalling is required for leptin regulation of energy balance but not reproduction. Nature, $\mathbf{2 0 0 3}, 421,856-9$.

[16] Rahmouni, K.; Haynes, W.G.; Morgan, D.A.; Mark, A.L. Intracellular mechanisms involved in leptin regulation of sympathetic outflow. Hypertension, 2003, 41, 763-7.

[17] Atherton, P.J.; Babraj, J.; Smith, K.; Singh, J.; Rennie, M.J.; Wackerhage, $\mathrm{H}$. S elective act ivation of A MPK-PGC-1alpha or P KBTSC2-mTOR signaling can expl ain specific adaptive responses to endurance or resistance training-like electrical muscle stimulation. FASEB J., 2005, 19, 786-8.

[18] Harris, R .B.; Mitchell, T.D.; Yan, X .; Simpson, J .S.; R edmann, S.M., J r. M etabolic r esponses to leptin in obes e $\mathrm{db} / \mathrm{db} \mathrm{m}$ ice ar e strain depend ent. Am. J. Physiol. Regul. Integr. Comp. Physiol., 2001, 281, R115-32.

[19] Fruhbeck, G.; J ebb, S.A.; P rentice, A .M. L eptin: phys iology and pathophysiology. Clin. Physiol., 1998, 18, 399-419.

[20] Sakurai, T.; Amemiya, A.; Ishii, M.; Matsuzaki, I.; Chemelli, R.M.; Tanaka, H .; Williams, S .C.; R ichardson, J .A.; K ozlowski, G .P.; Wilson, S .; A rch, J .R.; B uckingham, R .E.; H aynes, A .C.; C arr, S.A.; A nnan, R .S.; M cNulty, D .E.; L iu, W.S.; Terrett, J .A.; Elshourbagy, N .A.; B ergsma, D .J.; Yanagisawa, M. O rexins and orexin r eceptors: a $\mathrm{f}$ amily of hypothalamic $\mathrm{n}$ europeptides a nd $\mathrm{G}$ protein-coupled $\mathrm{r}$ eceptors $\mathrm{t}$ hat $\mathrm{r}$ egulate $\mathrm{f}$ eeding $\mathrm{b}$ ehavior. Cell, 1998, 92, 573-85.

[21] Dulloo, A.G.; Seydoux, J.; Jacquet, J. Adaptive thermogenesis and uncoupling p roteins: a reappraisal of their roles in fat m etabolism and energy balance. Physiol. Behav., 2004, 83, 587-602.

[22] Hosoda, H.; Kojima, M.; Kangawa, K. Ghrelin and the regulation of food intake and energy balance. Mol. Interv, 2002, 2, 494-503.

[23] Hosoda, H .; K ojima, M.; K angawa, K. B iological, phys iological, and pharmacological as pects of ghrelin. J. Pharmacol. Sci., 2006, $100,398-410$

[24] Zhang, J.V.; Ren, P.G.; Avsian-Kretchmer, O.; Luo, C.W.; Rauch, R.; Klein, C.; Hsueh, A.J. Obestatin, a peptide encoded by the ghrelin gene, oppos es ghrelin's effects on f ood intake. Science, 2005, 310, 996-9.

[25] van der Lely, A.J.; Tschop, M.; Heiman, M.L.; Ghigo, E. Biological, physiological, pathophysiological, and pharmacological aspects of ghrelin. Endocr. Rev., 2004, 25, 426-57.

[26] Wren, A.M.; S eal, L.J .; C ohen, M.A.; B rynes, A .E.; F rost, G .S.; Murphy, K.G.; D hillo, W.S.; G hatei, M.A.; B loom, S .R. G hrelin enhances appetite and increases food intake in humans. J. Clin. Endocrinol. Metab., 2001, 86, 5992.

[27] Bachman, E.S.; Dhillon, H.; Zhang, C.Y.; Cinti, S.; Bianco, A.C.; Kobilka, B .K.; Lo well, B.B. b etaAR s ignaling r equired f or dietinduced thermogenesis and obes ity resistance. Science, 2002, 297, 843-5.

[28] Rousset, S.; A lves-Guerra, M.C.; Mozo, J.; Miroux, B .; CassardDoulcier, A.M.; Bouillaud, F.; R icquier, D. Th e b iology of m itochondrial uncoupling proteins. Diabetes, 2004, 53. Suppl. 1, S13035 .

[29] Robidoux, J.; M artin, T.L.; Co llins, S . Be ta-adrenergic re ceptors and regulation of energy expenditure: a f amily affair. Annu. Rev. Pharmacol. Toxicol., 2004, 44, 297-323.

[30] Lafontan, M.; Berlan, M. Fat cell alpha 2-adrenoceptors: the regulation of $\mathrm{f}$ at $\mathrm{c}$ ell $\mathrm{f}$ unction a nd lip olysis. Endocr. Rev., 1995, 16, 716-38.

[31] Arner, P. Catecholamine-induced lipolysis in obesity. Int. J. Obes. Relat. Metab. Disord., 1999, 23. Suppl. 1, 10-13.

[32] Stich, V.; D e G lisezinski, I .; C rampes, F.; H ejnova, J .; CottetEmard, J .M.; G alitzky, J .; La fontan, M .; R iviere, D .; B erlan, M. Activation of al pha(2)-adrenergic $\mathrm{r}$ eceptors i mpairs exer ciseinduced lipolysis in SCAT of obese subjects. Am. J. Physiol. Regul. Integr. Comp. Physiol., 2000, 279, R499-504.

[33] Lafontan, M. Fat cells: a fferent and ef ferent messages define new approaches to treat obesity. Annu. Rev. Pharmacol. Toxicol., 2005, 45, 119-46.

[34] Frayn, K.N. Adipose tissue as a buffer for daily lipid flux. Diabe- tologia, 2002, 45, 1201-10.

[35] Dodt, C.; Lonnroth, P.; Fehm, H.L.; Elam, M. The subcutaneous lipolytic response to regional neural stimulation is reduced in obese women. Diabetes, 2000, 49, 1875-9.

[36] Schiffelers, S .L.; S aris, W.H.; Bo omsma, F.; v an Ba ak, M .A beta(1)- and bet a(2)-Adrenoceptor-mediated $t$ hermogenesis and lipid utilization in obese and lean men. J. Clin. Endocrinol. Metab., 2001, 86, 2191-9.

[37] Stahl, A.; Evans, J.G.; Pattel, S .; H irsch, D .; Lo dish, H.F. Insulin causes fatty acid transport protein translocation and enhanced fatty acid uptake in adipocytes. Dev. Cell, 2002, 2, 477-88.

[38] Zierath, J.R.; Livingston, J.N.; Thorne, A.; Bolinder, J.; Reynisdottir, S.; Lonnqvist, F.; Arner, P. Regional difference in insulin inhibition of non-esterified fatty acid release from hum an adipocytes: relation to insulin receptor phosphorylation and intracellular signalling through the insulin receptor s ubstrate-1 pat hway. Diabetologia, 1998, 41, 1343-54.

[39] Sengenes, C.; Bo uloumie, A .; Hauner, H .; Be rlan, M.; Bu sse, R.; Lafontan, M .; G alitzky, J . I nvolvement o f a c GMP-dependen pathway in the natriuretic p eptide-mediated h ormone-sensitive lipase phosphorylation in hum an adipocytes. J. Biol. Chem., 2003 278, 48617-26.

[40] Yip, R.G.; Goodman, H.M. Growth hor mone and dex amethasone stimulate lipolysis and a ctivate adenylyl cyclase in rat adipocytes by selectively shifting $\mathrm{Gi}$ alpha2 to lower density membrane fractions. Endocrinology, 1999, 140, 1219-27.

[41] Gaudiot, N .; J aubert, A .M.; C harbonnier, E. ; S abourault, D .; La casa, D .; Giudicelli, Y.; R ibiere, C . Modulation of w hite a dipose tissue lip olysis by n itric oxide. J. Biol. Chem., 1998, 273, 1347581.

[42] Bing, C.; Bao, Y.; Jenkins, J.; Sanders, P.; Manieri, M.; Cinti, S.; Tisdale, M.J.; Trayhurn, P. Zinc-alpha2-glycoprotein, a lipid mobilizing factor, is expressed in adipocytes and is up-regulated in mice with cancer cachexia. Proc. Natl. Acad. Sci. USA, 2004, 101, 25005 .

[43] McGarry, J.D. B anting l ecture 2001: dys regulation of fatty aci d metabolism in the etiology of type 2 diabetes. Diabetes, 2002, 51, 7-18.

[44] Margetic, S.; Gazzola, C.; Pegg, G.G.; Hill, R.A. Leptin: a review of its peripheral actions and interactions. Int. J. Obes. Relat. Metab. Disord., 2002, 26, 1407-33.

[45] Lyngso, D .; Si monsen, L .; Bulow, J . Interleukin-6 production in human subcutaneous abdominal adipose tissue: the effect of exercise. J. Physiol., 2002, 543, 373-8.

[46] Ukkola, O .; S antaniemi, M. A diponectin: a lin k b etween e xcess adiposity a nd a ssociated c omorbidities? J. Mol. Med., 2002, 80, 696-702.

[47] Ouchi, N .; O hishi, M .; K ihara, S.; Funahashi, T.; N akamura, T.; Nagaretani, H.; Kumada, M.; Ohashi, K.; Okamoto, Y.; Nishizawa, H.; Ki shida, K. ; M aeda, N. ; Na gasawa, A. ; Ko bayashi, H. ; Hiraoka, H.; Komai, N.; Kaibe, M.; Rakugi, H.; O gihara, T.; Matsuzawa, Y. A ssociation of hypoa diponectinemia w ith i mpaired vasoreactivity. Hypertension, 2003, 42, 231-4.

[48] Hardie, D.G. Minireview: the A MP-activated protein ki nase cas cade: the key sensor of cellular energy status. Endocrinology, 2003, 144, 5179-83.

[49] Steppan, C.M.; Bailey, S.T.; Bhat, S.; Brown, E.J.; Banerjee, R.R.; Wright, C.M.; Patel, H.R.; Ahima, R.S.; Lazar, M.A. The hormone resistin links obesity to diabetes. Nature, 2001, 409, 307-12.

[50] Apovian, C.M.; Bigornia, S.; Mott, M.; Meyers, M.R.; Ulloor, J .; Gagua, M.; McDonnell, M.; Hess, D.; Joseph, L.; Gokce, N. Ad ipose $\mathrm{m}$ acrophage in filtration is a ssociated $\mathrm{w}$ ith in sulin $\mathrm{r}$ esistance and vascular end othelial d ysfunction in obese s ubjects. Arterioscler. Thromb. Vasc. Biol., 2008, 28, 1654-9.

[51] Lee, Y.H.; P ratley, R .E. Th e e volving $r$ ole of in flammation in obesity and the metabolic syndrome. Curr. Diab. Rep., 2005, 5, 705 .

[52] Xu, H .; B arnes, G .T.; Yang, Q .; Tan, G .; Yang, D .; C hou, C .J.; Sole, J.; Nichols, A.; Ross, J.S.; Tartaglia, L.A.; Chen, H. Chronic inflammation in fat plays a crucial role in the development of obesity-related insulin resistance. J. Clin. Invest., 2003, 112, 1821-30.

[53] van Ro ssum, E. F.; N icklas, B. J.; D ennis, K .E.; Be rman, D .M.; Goldberg, A.P. Leptin responses to weight loss in postmenopausal women: relationship to sex-hormone binding globulin and visceral obesity. Obes. Res., 2000, 8, 29-35.

[54] Campfield, L.A.; Smith, F.J. Overview: neurobiology of OB pro- 
tein (leptin). Proc. Nutr. Soc., 1998, 57, 429-40.

[55] Ahima, R.S.; O sei, S.Y. Le ptin s ignaling. Physiol. Behav., 2004, 81, 223-41.

[56] Mlinar, B.; Marc, J.; Janez, A.; Pfeifer, M. Molecular mechanisms of i nsulin $\mathrm{r}$ esistance and as sociated di seases. Clin. Chim. Acta, 2007, 375, 20-35.

[57] Casteilla, L.; C ousin, B .; C armona, M. P PARs a nd A dipose C ell Plasticity. PPAR Res., 2007, 2007, 68202.

[58] Rankinen, T.; Zuberi, A.; Chagnon, Y.C.; Weisnagel, S.J.; Argyropoulos, G.; Walts, B.; Perusse, L.; Bouchard, C. The human obesity gene map: the 2005 update. Obesity (Silver Spring), 2006, 14, 52944.

[59] Azuma, N.; Yoshimasa, Y.; Nishimura, H.; Yamamoto, Y.; Masuzaki, H.; Suga, J.; Shigemoto, M.; Matsuoka, N.; Tanaka, T.; Satoh, N.; Igaki, T.; Miyamoto, Y.; Itoh, H.; Yoshimasa, T.; Hosoda, K.; Nishi, S.; Nakao, K. The significance of the Trp 64 Arg mutation of the b eta3-adrenergic r eceptor $g$ ene in im paired g lucose to lerance, non-insulin-dependent di abetes mellitus, a nd in sulin r esistance in Japanese subjects. Metabolism, 1998, 47, 456-60.

[60] Straczkowski, M ; D zienis-Straczkowska, S .; S tepien, A .; K owalska, I.; Szelachowska, M.; Kinalska, I. P lasma interleukin-8 concentrations a re increased in obese subjects and related to fat mass and tumor necrosis factor-alpha s ystem. J. Clin. Endocrinol. Metab., 2002, 87, 4602-6.

[61] Specchia, C.; Barlera, S.; Chiodini, B.D.; Nicolis, E.B.; Farrall, M.; Peden, J .; C ollins, R .; Watkins, H .; Tognoni, G.; F ranzosi, M.G. Quantitative tr ait g enetic lin kage a nalysis of body mass in dex in familial coronary artery disease. Hum. Hered., 2008, 66, 19-24.

[62] Jhanwar-Uniyal, M.; Beck, B.; Jhanwar, Y.S.; Burlet, C.; Leibowitz, S.F. Neuropeptide Y projection from arcuate nucleus to parvocellular division of paraventricular nucleus: specific relation to the ingestion of carbohydrate. Brain Res., 1993, 631, 97-106.

[63] Lee, M.; Korner, J. Review of physiology, clinical manifestations, and $\mathrm{m}$ anagement of hy pothalamic obesity i n hum ans. Pituitary, 2008.

[64] Weaver, J.U. Classical endocrine di seases causing ob esity. Front. Horm. Res., 2008, 36, 212-28.

[65] Ness-Abramof, R. ; A povian, C. M. D rug-induced w eight $\mathrm{g}$ ain. Timely. Top. Med. Cardiovasc. Dis., 2005, 9, E31.

[66] Mattes, R .D. Food pal atability, $r$ heology, a nd $\mathrm{m}$ eal $\mathrm{p}$ atterning. JPEN. J. Parenter. Enteral. Nutr., 2008, 32, 572-4.

[67] Blundell, J.E.; Gillett, A. Control of food intake in the obese. Obes. Res., 2001, 9. Suppl. 4, 263S-70S.

[68] Hill, J.O.; Wyatt, H.R. Role of physical activity in preventing and treating obesity. J. Appl. Physiol., 2005, 99, 765-70.

[69] Ravussin, E.; Valencia, M .E.; Es parza, J .; B ennett, P.H.; S chulz, L.O. Effects of a traditional lif estyle on o besity in P ima Indians. Diabetes Care, 1994, 17, 1067-74.

[70] Schulz, L.O.; Bennett, P.H.; Ravussin, E.; Kidd, J.R.; Kidd, K.K.; Esparza, J.; Valencia, M.E. Effects of traditional and western environments on prevalence of type 2 diabetes in Pima Indians in Mexico and the U.S. Diabetes Care, 2006, 29, 1866-71.

[71] Campfield, L.A.; S mith, F.J.; B urn, P. S trategies and potential molecular targets for obesity treatment. Science, 1998, 280, 1383-7.

[72] Yanovski, S.Z.; Yanovski, J.A. O besity. N. Engl. J. Med., 2002, 346, 591-602.

[73] Scott, S. ( 2000). T he P rescription, $20 \mathrm{E}$ dition ( Baltimore MD: Lippincott Williams and Wilkins).

[74] Steelman, M.; Tiedt, T. L ong-term phar macotherapy in the $\mathrm{m}$ anagement of o besity. National Task F orce o $n$th e Prevention a nd Treatment of Obesity. JAMA, 1996, 276, 1907-15.

[75] Steelman, M . Pharmacotherapy i $\mathrm{n} t$ he man agement of ob esity. JAMA, 1997, 277, 1201-2; author reply 1202 .

[76] Guy-Grand, B. Clinical studies with dexfenfluramine: from past to future. Obes. Res., 1995, 3. Suppl. 4, 491S-6S.

[77] Goldstein, D. J.; R ampey, A. H., J r.; E nas, G. G.; P otvin, J. H.; Fludzinski, L.A.; Levine, L.R. Fluoxetine: a $\mathrm{r}$ andomized cl inical trial in the treatment of obesity. Int. J. Obes. Relat. Metab. Disord., 1994, 18, 129-35.

[78] Bach, D.S.; Rissanen, A.M.; Mendel, C.M.; Shepherd, G.; Weinstein, S .P.; K elly, F.; S eaton, T.B.; Patel, B .; P ekkarinen, T.A.; Armstrong, W.F. A bsence of car diac valve dysfunction in o bese patients treated with sibutramine. Obes. Res., 1999, 7, 363-9.

[79] James, W.P.; A strup, A .; F iner, N .; H ilsted, J .; K opelman, P.; Rossner, S.; Saris, W.H.; Van Gaal, L.F. Effect of sibutramine on weight maintenance after weight loss: a randomised trial. STORM
Study Group. Sibutramine Trial of Obesity Reduction and Maintenance. Lancet, 2000, 356, 2119-25.

[80] Padwal, R.S.; Majumdar, S.R. Drug treatments for obesity: orlistat, sibutramine, and rimonabant. Lancet, 2007, 369, 71-7.

[81] Akbas, F.; G asteyger, C.; Sjodin, A .; A strup, A .; La rsen, T.M. A critical review of the cannabinoid receptor as a drug target for obesity management. Obes. Rev., 2008.

[82] Jbilo, O.; Ravinet-Trillou, C.; Arnone, M.; Buisson, I.; Bribes, E.; Peleraux, A.; Penarier, G.; Soubrie, P.; Le Fur, G.; Galiegue, S .; Casellas, $\mathrm{P}$. The $\mathrm{CB} 1$ receptor a ntagonist rim onabant reverses the diet-induced obesity phenotype through the regulation of lipolysis and energy balance. FASEB J., 2005, 19, 1567-9.

[83] Sjostrom, L.; R issanen, A.; A ndersen, T.; Boldrin, M.; Golay, A .; Koppeschaar, H .P.; K rempf, M. R andomised pl acebo-controlled trial of o rlistat for w eight lo ss a nd p revention of w eight regain in obese patients. European Multicentre Orlistat Study Group. Lancet, 1998, 352, 167-72.

[84] Heck, A. M.; Yanovski, J. A.; C alis, K. A. Or listat, a n ew 1 ipase inhibitor for the management of obesity. Pharmacotherapy, 2000, 20, 270-9.

[85] Davidson, M .H.; H auptman, J .; D iGirolamo, M.; F oreyt, J .P.; Halsted, C.H.; Heber, D.; Heimburger, D.C.; Lucas, C.P.; Robbins, D.C.; Ch ung, J.; H eymsfield, S.B. Weight c ontrol a nd risk fa ctor reduction in obese subjects treated for 2 year s with orlistat: a randomized controlled trial. JAMA, 1999, 281, 235-42.

[86] Drew, B.S.; Dixon, A.F.; Dixon, J.B. Obesity management: update on orlistat. Vasc. Health Risk Manag., 2007, 3, 817-21.

[87] MacWalter, R.S.; Fraser, H.W.; Armstrong, K.M. Orlistat enhances warfarin effect. Ann. Pharmacother., 2003, 37, 510-12.

[88] Zhi, J.; Moore, R.; Kanitra, L.; Mulligan, T.E. Effects of orlistat, a lipase inhibitor, on the pharmacokinetics of three highly lip ophilic drugs (amiodarone, fluoxetine, and s imvastatin) in healthy volunteers. J. Clin. Pharmacol., 2003, 43, 428-35.

[89] Zhi, J .; M oore, R .; K anitra, L .; M ulligan, T.E. P harmacokinetic evaluation of the possible interaction between selected concomitant medications and orlistat at steady state in healthy subjects. J. Clin. Pharmacol., 2002, 42, 1011-19.

[90] Stahl, A.; Hirsch, D.J.; Gimeno, R.E.; Punreddy, S.; Ge, P.; Watson, N.; Patel, S.; Kotler, M.; Raimondi, A.; Tartaglia, L.A.; Lodish, H.F. I dentification of the $m$ ajor in testinal fatty a cid transport protein. Mol. Cell, 1999, 4, 299-308.

[91] Smith, S.J.; Cases, S.; Jensen, D.R.; Chen, H.C.; Sande, E.; Tow, B.; Sanan, D.A.; Raber, J .; Eckel, R.H.; F arese, R.V., J r. Obesity resistance a nd $\mathrm{m}$ ultiple $\mathrm{m}$ echanisms of $\mathrm{fr}$ iglyceride $\mathrm{s}$ ynthesis in mice lacking Dgat. Nat. Genet., 2000, 25, 87-90.

[92] Lowell, B.B. A daptive th ermogenesis: tu rning o $\mathrm{n}$ th e h eat. Curr. Biol., 1998, 8, R517-20.

[93] Ribeiro, M.O.; Carvalho, S.D.; Schultz, J.J.; Chiellini, G.; Scanlan, T.S.; Bianco, A.C.; Brent, G.A. Thyroid hormone--sympathetic interaction and adaptive thermogenesis are thyroid hormone receptor isoform--specific. J. Clin. Invest., 2001, 108, 97-105.

[94] Ribeiro, M.O. Effects of thyroid hormone analogs on lipid metabolism and thermogenesis. Thyroid, 2008, 18, 197-203.

[95] Weyer, C.; Gautier, J.F.; Danforth, E., Jr. Development of beta 3 adrenoceptor agonists for the treatment of obesity and diabetes-an update. Diabetes Metab., 1999, 25, 11-21.

[96] de Souza, C.J.; Burkey, B.F. Beta 3-adrenoceptor agonists as antidiabetic a nd a nti-obesity d rugs in humans. Curr. Pharm. Des., 2001, 7, 1433-49.

[97] Dow, R.L. B eta3-adrenergic a gonists: $p$ otential th erapeutics f or obesity. Expert Opin. Investig. Drugs, 1997, 6, 1811-25.

[98] Harada, H. ; Hi rokawa, Y.; S uzuki, K. ; Hi yama, Y.; Ou e, M .; Kawashima, H.; Kato, H.; Yoshida, N.; Furutani, Y.; Kato, S. Discovery of a novel and potent human and rat beta3-adrenergic receptor a gonist, [3 -[(2R)-[[(2R)-(3-chlorophenyl)-2-hydroxyethyl] amino]propyl]-1H-indol-7-y loxy]acetic acid. Chem. Pharm. Bull. (Tokyo), 2005, 53, 184-98.

[99] Nedergaard, J ; G olozoubova, V.; M atthias, A ; A sadi, A .; J acobsson, A.; Cannon, B. UCP1: the only protein able to mediate adaptive non-shivering thermogenesis and met abolic i nefficiency. Biochim. Biophys. Acta, 2001, 1504, 82-106.

[100] Boss, O .; H agen, T.; L owell, B.B. Uncoupling proteins 2 a nd 3: potential regulators of mitochondrial energy metabolism. Diabetes, 2000, 49, 143-56.

[101] Schrauwen, P.; Hesselink, M. UCP2 and UCP3 in muscle controlling body metabolism. J. Exp. Biol., 2002, 205, 2275-85. 
[102] Wu, Z.; Puigserver, P.; S piegelman, B.M. T ranscriptional activation of adipogenesis. Curr. Opin. Cell Biol., 1999, 11, 689-94.

[103] Wood, J.G.; Rogina, B.; Lavu, S.; Howitz, K.; Helfand, S.L.; Tatar, M.; Sinclair, D. Sirtuin activators mimic caloric restriction and delay ageing in metazoans. Nature, 2004, 430, 686-9.

[104] Chen, D.; Guarente, L. SIR2: a pot ential target for calorie restriction mimetics. Trends Mol. Med., 2007, 13, 64-71.

[105] Picard, F.; Kurtev, M.; Chung, N.; Topark-Ngarm, A.; Senawong, T.; Machado D e Oliveira, R .; Le id, M .; McBurney, M.W.; Guarente, L. S irt1 promotes fat mobilization in white adipocytes by repressing PPAR-gamma. Nature, 2004, 429, 771-6.

[106] Bordone, L.; Motta, M.C.; Picard, F.; R obinson, A .; J hala, U .S.; Apfeld, J .; McDonagh, T.; Le mieux, M.; McBurney, M.; Szilvasi, A.; Ea slon, E.J .; L in, S .J.; Guarente, L. Sirt1 regulates in sulin secretion by $r$ epressing UCP2 in pancreatic bet a cells. PLoS Biol., 2006, 4, e31.

[107] Rodgers, J.T.; Lerin, C.; Haas, W.; Gygi, S.P.; Spiegelman, B.M.; Puigserver, P. N utrient cont rol of gl ucose homeostasis through a complex of PGC-1alpha and SIRT1. Nature, 2005, 434, 113-18.

[108] Baur, J.A.; Pearson, K.J.; Price, N.L.; Jamieson, H.A.; Lerin, C .; Kalra, A.; Prabhu, V.V.; Allard, J.S.; Lopez-Lluch, G.; Lewis, K.; Pistell, P.J.; Poosala, S.; Becker, K.G.; Boss, O.; Gwinn, D.; Wang, M.; Ramaswamy, S.; Fishbein, K.W.; Spencer, R.G.; Lakatta, E.G.; Le C outeur, D .; S haw, R .J.; N avas, P.; P uigserver, P.; I ngram, D.K.; de Cabo, R.; Sinclair, D.A. Resveratrol improves health and survival of mice on a high-calorie diet. Nature, 2006, 444, 337-42.

[109] Carsten, R.E.; Bachand, A.M.; Bailey, S.M.; Ullrich, R.L. Resveratrol reduces radiation-induced chromosome aber ration frequencies in mouse bone marrow cells. Radiat. Res., 2008, 169, 633-8.

[110] Saiko, P.; Szakmary, A.; Jaeger, W.; Szekeres, T. Resveratrol and its analogs: defense against cancer, coronary disease and neurodegenerative maladies or just a fad? Mutat. Res., 2008, 658, 68-94.

[111] Miller, N.J.; Rice-Evans, C.A. Antioxidant activity of resveratrol in red wine. Clin. Chem., 1995, 41, 1789.

[112] Baur, J.A.; Sinclair, D.A. Therapeutic p otential of resveratrol: the in. vivo evidence. Nat. Rev. Drug Discov., 2006, 5, 493-506.

[113] Milne, J.C.; Lambert, P.D.; Schenk, S.; Carney, D.P.; Smith, J.J.; Gagne, D.J.; Jin, L.; Boss, O.; Perni, R.B.; Vu, C.B.; Bemis, J.E.; Xie, R.; Disch, J.S.; Ng, P.Y.; Nunes, J.J.; Lynch, A.V.; Yang, H.; Galonek, H.; Israelian, K.; Choy, W.; Iffland, A.; Lavu, S.; Medvedik, O.; Sinclair, D.A.; Olefsky, J.M.; Jirousek, M.R.; Elliott, P.J.; Westphal, C.H. Small molecule activators of SIRT1 as therapeutics for the treatment of type 2 diabetes. Nature, 2007, 450, 712-16.

[114] Scarpello, J.H.; Howlett, H.C. Metformin therapy and clinical uses. Diab. Vasc. Dis. Res., 2008, 5, 157-67.

[115] Eurich, D .T.; M ajumdar, S .R.; M cAlister, F.A.; Tsuyuki, R .T.; Johnson, J .A. I mproved cl inical out comes as sociated $\mathrm{w}$ ith $\mathrm{m}$ etformin in patients w ith diabetes and heart failure. Diabetes Care, 2005, 28, 2345-51.

[116] Hundal, R .S.; K rssak, M. ; D ufour, S.; Laurent, D .; L ebon, V.; Chandramouli, V.; Inzucchi, S.E.; Schumann, W.C.; Petersen, K.F.; Landau, B.R.; Shulman, G.I. Mechanism by which metformin reduces glucose production in type 2 di abetes. Diabetes, 2000, 49, 2063-9.

[117] Zhou, G.; Myers, R.; Li, Y.; Chen, Y.; Shen, X.; Fenyk-Melody, J.; Wu, M.; Ventre, J .; D oebber, T.; Fujii, N.; M usi, N.; H irshman, M.F.; Goodyear, L.J.; Moller, D.E. Role of AMP-activated protein kinase in mechanism of $\mathrm{m}$ etformin action. J. Clin. Invest., 2001, 108, 1167-74.

[118] Dhahbi, J.M.; Mote, P.L.; Fahy, G.M.; Spindler, S.R. Identification of $\mathrm{p}$ otential $\mathrm{c}$ aloric $\mathrm{r}$ estriction $\mathrm{m}$ imetics b y $\mathrm{m}$ icroarray $\mathrm{p}$ rofiling. Physiol. Genomics, 2005, 23, 343-50.

[119] Ingram, D.K.; Zhu, M.; Mamczarz, J.; Zou, S.; Lane, M.A.; Roth, G.S.; deC abo, R . C alorie r estriction m imetics: an em erging $\mathrm{r}$ esearch field. Aging Cell, 2006, 5, 97-108.

[120] Nissen, S.E.; Wolski, K . E ffect of $r$ osiglitazone on $t$ he $r$ isk of myocardial i nfarction an deat h f rom car diovascular caus es. $N$. Engl. J. Med., 2007, 356, 2457-71.

[121] Wan, R .; C amandola, S .; Mattson, M.P. Intermittent f asting a nd dietary s upplementation $\mathrm{w}$ ith 2- deoxy-D-glucose i mprove f unctional and metabolic cardiovascular risk factors in rats. FASEB J., 2003, 17, 1133-4.
[122] Wolf, G. L eptin: the w eight-reducing pl asma protein e ncoded by the obese gene. Nutr. Rev., 1996, 54, 91-3.

[123] Kalra, S .P.; K alra, P.S. G ene-transfer te chnology: a p reventive neurotherapy to $\mathrm{c}$ urb obesity, a meliorate $\mathrm{m}$ etabolic syndrome and extend life expectancy. Trends Pharmacol. Sci., 2005, 26, 488-95.

[124] Farooqi, I.S.; Jebb, S.A.; Langmack, G.; Lawrence, E.; Cheetham, C.H.; Prentice, A.M.; Hughes, I.A.; McCamish, M.A.; O'Rahilly, S. Effects of r ecombinant le ptin th erapy in a $\mathrm{c}$ hild $\mathrm{w}$ ith $\mathrm{c}$ ongenital leptin deficiency. N. Engl. J. Med., 1999, 341, 879-884.

[125] Mantzoros, C.S.; Flier, J.S. Editorial: leptin as a therapeutic agent-trials and tribulations. J. Clin. Endocrinol. Metab., 2000, 85, 40002.

[126] Ettinger, M.P.; Litt lejohn, T.W.; S chwartz, S.L.; Weiss, S.R.; McIlwain, H. H.; He ymsfield, S .B.; B ray, G. A.; R oberts, W.G.; Heyman, E.R.; Stambler, N .; H eshka, S .; Vicary, C .; G uler, H.P. Recombinant variant of c iliary neurotrophic factor for w eight loss in obes e adults: a $\mathrm{r}$ andomized, d ose-ranging s tudy. JAMA, $\mathbf{2 0 0 3}$ 289, 1826-32.

[127] Foster-Schubert, K .E.; C ummings, D .E. E merging t herapeutic strategies for obesity. Endocr. Rev., 2006, 27, 779-93.

[128] Xu, J.; Li, L.; Qian, Z.; Hong, J.; Shen, S.; Huang, W. Reduction of PTP1B by RNAi upregulates the activity of insulin controlled fatty acid s ynthase promoter. Biochem. Biophys. Res. Commun., 2005, $329,538-43$.

[129] Chen, X .; M atthews, J .; Zh ou, L.; P elton, P.; Lia ng, Y.; X u, J .; Yang, M.; Cryan, E.; Rybczynski, P.; Demarest, K. Improvement of dyslipidemia, insulin sensitivity, and energy balance by a peroxisome pr oliferator-activated $\mathrm{r}$ eceptor al pha ag onist. Metabolism, 2008, 57, 1516-25.

[130] Guo, Q.; Sahoo, S.P.; Wang, P.R.; Milot, D.P.; Ippolito, M.C.; Wu, M.S.; B affic, J.; B iswas, C .; Hernandez, M.; La m, M.H.; S harma N.; H an, W.; K elly, L .J.; M acNaul, K .L.; Z hou, G .; D esai, R .; Heck, J .V.; D oebber, T.W.; B erger, J .P.; Moller, D .E.; S parrow, C.P.; Chao, Y.S.; Wright, S.D. A novel per oxisome proliferatoractivated $\mathrm{r}$ eceptor al pha/gamma dual ago nist demons trates favorable effects on lipid homeostasis. Endocrinology, 2004, 145, 1640 8 .

[131] Kasai, S.; Inoue, T .; Yoshitomi, H .; H ihara, T .; M atsuura, F.; Harada, H .; S hinoda, M .; Tanaka, I . A ntidiabetic and hypolipidemic effects of a novel dual peroxisome proliferator-activated receptor (PPAR) al pha/gamma ago nist, E 3030, in $\mathrm{db} / \mathrm{db} \mathrm{m}$ ice and beagle dogs. J. Pharmacol. Sci., 2008, 108, 40-8.

[132] Ioannides-Demos, L .L.; P roietto, J .; Tonkin, A .M.; M cNeil, J .J. Safety of drug therapies used for weight loss and treatment of obesity. Drug Saf., 2006, 29, 277-302.

[133] Maddika, S .; A nde, S. R.; Panigrahi, S .; Paranjothy, T.; Weglarczyk, K.; Zuse, A.; Eshraghi, M.; Manda, K.D.; Wiechec, E.; Los, M. Cell survival, cell death and cell cycle pathways are interconnected: implications for cancer therapy. Drug Resist. Updat, 2007, 10, 13-29.

[134] Maddika, S.; Ande, S.R.; Wiechec, E.; Hansen, L.L.; Wesselborg, S.; L os, M. A kt-mediated phos phorylation of CDK2 regulates its dual role in cell cycle progression and apoptosis. J. Cell Sci., 2008, 121, 979-88.

[135] Maddika, S.; B ay, G.H.; Kroczak, T.J.; Ande, S.R.; Maddika, S .; Wiechec, E.; G ibson, S.B.; Los, M. Akt is transferred to the nucleus of cells treated w ith a poptin, a nd it $\mathrm{p}$ articipates in a poptininduced cell death. Cell Prolif., 2007, 40, 835-48.

[136] Rashedi, I.; Panigrahi, S.; Ezzati, P.; Ghavami, S.; Los, M. Autoimmunity an d a poptosis--therapeutic i mplications. Curr. Med. Chem., 2007, 14, 3139-51

[137] Seale, P.; Bjork, B.; Yang, W.; Kajimura, S.; Chin, S.; Kuang, S.; Scime, A .; D evarakonda, S .; C onroe, H.M.; E rdjument-Bromage, H.; T empst, P.; Rudnicki, M .A.; Beier, D.R.; S piegelman, B.M. PRDM16 c ontrols a $\mathrm{b}$ rown $\mathrm{f}$ at/skeletal $\mathrm{m}$ uscle $\mathrm{s}$ witch. Nature 2008, 454, 961-7.

[138] Alberti, E.A .; Lo s, M.; G arcía, R .; F raga, J .L.; Serrano, T.; Hernández, E.; Klonisch, T.; Macías, R.; Martínez, L.; Castillo, L.; de 1 a $C$ uétara, $K$. P rolonged s urvival a nd e xpression of neural markers b y Bo ne $\mathrm{M}$ arrow-Derived $\mathrm{S}$ tem Ce lls t ransplanted i nto brain lesions. Med. Sci. Monit., 200!, 1], BR47-54. 